\title{
Egiak, munduak eta minak
}

\author{
Truths, worlds and pains \\ EKAIN GARMENDIA*\& \\ Filosofia Saila eta ILCLI (UPV/EHU)
}

Saul Kripkek hiru hitzaldi eman zituen Princeton Unibertsitatean, 1970eko urtarrila bukaeran, Naming and Necessity izenburuarekin. ${ }^{1}$ Hasieratik izan zuen Kripkek asmoa hitzaldi horietan azaldutakoak hartu, ideia nagusiak errebisatu eta zabaldu, hitzaldietako edukiak idatzizko testu batean atondu, eta horiek denak liburu batean txukun argitaratzeko, baina urteek aurrera egin ahala konturatu zen, hitzaldietan esandako guztiak nahikoa detailerekin garatu arte itxoiten bazuen, horiek akaso ez zituela inoiz liburu batean argitaratuko. ${ }^{2}$ Horrela, bada, 1980an, Princetonen hitzaldiak eman eta hamar urtera, idatzizko transkripzio bat argitaratu zuen, idatzizko bertsioak eskatzen dituen aldaketa gutxi batzuk sartuta, hitzaldi sortak zeukan izenburu berarekin (Kripke 1980) -ez zen transkripzioa argitaratzen zen lehen aldia: 1972an Donald Davidson eta Gilbert Harmanek argitaratutako bilduma batean agertu zen aurrena, kapitulu moduan-. 2020an urteurren borobil bikoitza daukagula aprobetxatuz (50 urte Kripkek hitzaldiak eman zi-

\footnotetext{
\& Eskerrak eman nahi dizkiet María de Ponte, Joana Garmendia, Kepa Korta eta Larraitz Zubeldiari, ale hau aurrera ateratzeko hartutako lanagatik, eta bai hitzaurre honi bai ale honetan argitaratu dugun itzulpenari egin dizkioten ohar eta zuzenketa guztiengatik. Lan hau egiteko Eusko Jaurlaritzak (IT1032-16) eta Espainiako Gobernuak (PID2019-106078GB-I00 (MCI/AEI/FEDER/ UE)) emandako diru-laguntzak baliatu ditut.

1 Izendatzea eta Beharrezkotasuna, euskaraz. Tamalez, euskaraz galdu egiten ditugu jatorrizko izenburuan dauden bi $\mathrm{N}$ handi horiek. Hemendik aurrerakoan, $N \& N$ deituko diot, bada, liburuari.

${ }^{2}$ Halaxe dio $N \& N r e n$ 1980ko edizioari idatzitako hitzaurrearen lehenengo lerroetan (Kripke 1980: lehenengo orrian bertan).
}

\footnotetext{
* Harremanetan jartzeko / Corresponding author: Ekain Garmendia. Filosofia Saila. Tolosa Etorbidea, 70, 20018 Donostia. ekain.garmendia@ehu.eus - https://orcid.org/0000-0001-6708-4323

Nola aipatu / How to cite: Garmendia, Ekain (2021). "Egiak, munduak eta minak", Gogoa, 22, 3-59. (https://doi.org/10.1387/ gogoa.22606).

Aurrena online argitaratua: 2021-III-22.

ISSN 1577-9424 - eISSN 2444-3573 / (C) 2021 UPV/EHU
}

cc) (i) Lan hau Creative Commons Aitortu 4.0 Nazioartekoaren

lizentziapean dago 
tuela, 40 liburua argitaratu zela), Gogoan ale berezi labur hau argitaratzea erabaki dugu, aitzakia ona baita Kripkeren lanari buruz pare bat artikulu original bildu eta N\&N osatzen duten hitzaldietako bat itzultzeko. ${ }^{3}$

Hitzaldiak eman zituenerako, oraindik hogeita hamar urte ez zituela, Kripkek bazuen jada sona garaiko filosofia akademiko estatubatuarrean. Hemezortzi urterekin hasi zen, oraindik ikasketa ertainak bukatzeko zeuzkala, Journal of Symbolic Logic aldizkarian logika modalari buruzko artikuluak argitaratzen. ${ }^{4}$ Harvarden oraindik matematikako gradu ikasketak bukatzeko zeuzkanean, jada irakasle ari zen Yalen eta MITen, logika modalaren semantikari buruzko artikuluak idazten jarraitzen zuen, eta Ruth Barcan Marcus eta Willard Quineren tamainako filosofoekin eztabaida-mahaietan parte hartzen zuen, gai beren inguruan.

Kripkek hitzaldiak eman zituen garaian, 1960ko hamarkada bukaerako urte horietan, aldaketa-giroa nabari zen filosofia analitiko estatubatuarrean. Bada filosofo talde bat - gero gehienak "New Theory of Reference" deitu ohi denaren inguruan aritu ziren- urte horietan ideia berriak proposatzen hasi zena Hizkuntzaren Filosofian, Logika Filosofikoan, Metafisikan, Gogoaren Filosofian, Epistemologian edota Metafisikan, sarri norabide bertsuetan: Keith Donnellan, David Kaplan, David Lewis, Hilary Putnam eta John Perryri buruz ari naiz, adibidez. ${ }^{5}$ Mugimendu edo eskola filosofiko homogeneo bat osatu gabe (ezta gutxiago ere), uste dut esan dezakegula filosofo horiek bai osatzen dutela halako "olatu berri" bat garaiko giro filosofikoan, eta $N \& N$ aldi berean da hasten ari den olatu berri horren emaitza eta, batez ere, bultzada.

$N \& N k$ badauka beste autore batzuen ideien eragin zuzena. Adibidez, Kripkek hitzaldiak eman baino bi urte lehenago argitaratu zuen Keith Donnellanek "Reference and Definite Descriptions" —Donnellanek hor egin zuen deskripzio erreferentzial eta atributiboen arteko bereizketa aurrerago

\footnotetext{
3 Birusak agertu zaizkigu, lanak moteldu, datak gainera etorri, eta erabaki dugu 41 eta 51, borobilak ez, baina oso politak direla.

${ }^{4}$ Bada istorio bat, Kripkeri buruz hitz egitean sarri kontatzen dena. Antza, 1950eko hamarkada erdialdean Harvarden irakasle eta jada filosofo ezaguna zen Willard Quinek gutun bat jaso omen zuen, Saul Aaron Kripke izeneko norbaitek sinatuta (ez zuen Quinek haren berri). Urte horietan logika formal modalari buruz eztabaidatzen zirenak aipatzen zituen gutunean, ideia interesgarri batzuk aipatuz. Quinek erantzun omen zion gutunari, eta dena delako Kripke hori Harvardeko Filosofia Sailean hitzaldiren bat-edo ematera gonbidatu omen zuen. Diotenez, honako hau izan zen Kripkeren erantzuna: "Eskerrik asko gonbidapenagatik, baina nire amak dio aurrena institutukoak bukatu behar ditudala." Hamalau urte omen zeuzkan. Ez dakit zenbateraino den sinesgarria anekdota, idatzita NY Timeseko blog batean bakarrik ikusi dut (Morris 2011). Argitaratu egingo den testu batean akaso ez genuke horrelako zurrumurrurik idatzi behar, baina, tira, agian bai konta dezakegu oin-ohar txiki batean.

5 Ikus, adibidez: Donnellan (1966), Kaplan (1989), Lewis (1968, 1979), Putnam (1975) eta Perry (1977, 1979).
} 
garatu zen erreferentzia zuzenaren ideiaren aurrekari argia da, eta eragiten du, ziur asko, N\&Nko anti-deskriptibismoan-, eta, nahiz eta oraindik ideia horiek argitaratu gabe egon, Hilary Putnam ari zen jada, klase natural terminoen semantikari dagokionez, Kripkek N\&Nn proposatu zituen tesi ia berberak defendatzen. Nolanahi ere, Kripkeren lanak Donnellan edo Putnamen eragina badauka, are gehiago dauka Ruth Barcan Marcusek 1940ko hamarkadatik aurrera logika modalean egindako lanaren eragina. Barcan Marcusen itzala handia da Kripkeren obra ia osoan; 1960ko hamarkada hasieran logika modalaren inguruan Kripkek idatzi zituenak ezin dira ulertu ez badira kontuan hartzen Barcan Marcusek arlo horretan egin zituen aurrerapen formalak 1940ko eta 1950eko hamarkadetan. N\&Nn defendatzen dituen tesi ugari lehenago Barcan Marcusek berak proposatu zituen, eta beste ideia askotan ere nabaria da bere eragina. Adibidez, identitate-erlazioen beharrezkotasunaren tesia, N\&Nko lehenengo hitzaldiko hainbat argudioren oinarrian dagoena, Barcan Marcusena da; eta izen propioak "etiketa hutsak" direlako tesia ere defendatu zuen Barcan Marcusek lehenago (Kripkek ez du horrelakorik defendatzen $N \& N n$ esplizituki, baina ideia hori bat dator bere anti-deskriptibismoarekin). ${ }^{6}$

Nolanahi ere, Kripkeren lanak Barcan Marcusen eta garaiko beste autore batzuen eragina badauka ere, are handiagoa da $N \& N k$ garaiko giro filosofikoan izan zuen inpaktua. Aurrena, $N \& N n$ planteamendu eta erreminta kontzeptual berriak erabiltzen dituelako Kripkek, horiek lehenago egin ez zen punturaino garatuz. Adibidez, egia-modalitate desberdinen arteko erlazioei dagokienean egiten dituen oharrak lagungarriak dira oso gero Logika Filosofikoan edota Erreferentziaren Teorian argudio eta ikuskera berriak muntatu ahal izateko, edota designatzaile zurrunen nozioak berak eta mundu posibleen parafernaliak balio izango du Zientziaren, Hizkuntzaren nahiz Gogoaren Filosofietan argudio eta tesi berritzaileak plazaratu ahal izateko. Bestalde, erreminta kontzeptual berri horiek erabiliz argudio berritzaileak planteatzen dituelako eztabaida filosofiko tradizionaletan (deskriptibismoaren kontra Erreferentziaren Teorian, edo, materialismoaren kontra, Gogoaren Filosofian, adibidez), eta hor tesi eta ikuskera berriak ere proposatzen dituelako (kate kausal-historikoen ideia berea da Erreferentziaren teorian, adibidez).

\footnotetext{
${ }^{6}$ Egon da eztabaidarik Barcan Marcusen obrak Kripkeren lanean eta New Theories of Reference horretan izan zuen eraginari buruz, eta egon da, baita ere, eragin hori onartu ohi dena baino handiagoa dela defendatu duenik (ikus, adibidez, Smith 1995). Ez naiz eztabaida horietan sartuko hemen, ezta hasiko ere Barcan Marcusen lanak Kripkerenean daukan eragina aztertzen, horretarako beste testu oso bat beharko bainuke. Baina bai bota nahi nuke nire iritzia hemen, lotuta baitago sarrera honetan gai batzuk aurkezteko eta lantzeko dudan moduarekin: nahiz eta Barcan Marcusen eragina $N \& N n$ handia izan (oso handia), Kripkek bai egiten ditu ekarpen oso originalak (asko), sartzen da Barcan Marcusek landu ez dituen eztabaida eta arlo ugaritan, eta lortzen du horiek denak alor eta auzi pila bati eragiten dion posizio filosofiko batean kohesionatzea. Horietako batzuk aipatuko ditut testu honetan.
} 
$N \& N n$ Kripkek lortzen du berrikuntza kontzeptual eta argudio eta tesi filosofiko horiek bildu, eta arlo filosofiko desberdinei eragiten dien posizio filosofiko koherentea taxutzea, eta horrekin ekarpen handia egiten dio halako espazio filosofiko berri bati, abiapuntu bezala balio diezaiekeena "olatu berri" hori osatzen duten autoreei, eztabaida zahar nahiz berrietan argudio eta proposamen originalak osatzeko.

Sarrera honetan horiek azaltzen saiatuko naiz, gutxi gorabehera. Saiatuko naiz deskribatzen, azaletik bada ere, nolakoa zen 1960ko hamarkadan Kripkek akademia estatubatuarrean aurkitu zuen giro filosofikoa; zeintzuk diren, nire ustez behintzat, buruan zeuzkan erreferente filosofiko nagusiak; eta saiatuko naiz azaltzen, labur bada ere, nola baztertu zituen Kripkek atzean utzi nahi zuen joko-zelai filosofiko horri eusten dioten oinarri nagusiak, "olatu berri" bati bide eman ahal izateko xx. mende amaierako panorama filosofikoan.

\section{Egia motak eta erlazio intermodalak}

Baiezpenak izan daitezke egiazkoak ala faltsuak, eta izan daitezke egiazkoak modu ugaritan. Adibidez, baiezpen bat izan daiteke egiazko analitikoki, edo egiazko a priori, edo egiazko derrigorrez, edo sintetikoki, edo a posteriori, edo kontingenteki. Egiazko izateko modu horiek egiaren alderdi desberdinei dagozkie eta, horrela, ohikoa da modu horiek hiru modalitate desberdinetan banatzea: badaude modalitate semantikoa, epistemikoa eta metafisikoa. N\&Nn, aurrena, Kripkek modalitate horien arteko erlazio kontzeptualak pixka bat argitzen ditu, "beharrezko" eta "a priori" bezalako kategoriak kontzeptualki behintzat desberdinak direla mantenduz. Halaber, a priori izan gabe beharrezkoak diren egiak badaudela eta beharrezkoak izan gabe a priori diren egiak ere badaudela defendatzen du, tradizio filosofikoak onartu izan zuenaren aurka. N\&Nko lehenengo orrietan horrelakoei buruz ari dela, beraz, egia-modalitateen arteko erlazioak ulertzeko modu berri bat aurkezten du Kripkek; horrekin, tradizio filosofiko batzuetan paper egituratzailea jokatu izan duten tesiak baztertzen ditu, eta hitzaldietan behin eta berriz erabiltzen dituen kontzeptu batzuk aurkezteko eta argitzeko aprobetxatzen du. Hori eginda, garaiko filosofoek gai horiek ulertzeko eta lantzeko zeukaten moduan eragin zuen, izugarri. Bota diezaiogun begiratua horri.

Azalpenak ematerakoan hasieratik hastea komeni omen da; has gaitezen, beraz, "Naming and Necessity" izenburuarekin. Izenburua bera 1947an Rudolf Carnapek argitaratu zuen Meaning and Necessity liburuari erreferentzia ez oso disimulatua da. Testu horretan Carnapek lehenago garatu ziren logika-sistema modalentzat semantika formala proposatzen $\mathrm{du}$, mundu posibleen nozioa erabiliz —edo, hobe, geroago "mundu posibleen semantikak" esan izan zaienen oinarrizko kontzeptu eta ideiak erabiliz-. Kripkek arlo horietan egin 
zuen lan formalak ${ }^{7}$ Carnapen eragin handia dauka (ez dago Kripkerik Carnapik gabe), baina, aldi berean, Kripkek beharrezkotasuna eta antzeko nozio modalak ulertzeko daukan moduak guztiz baztertzen ditu Carnapek Meaning and Necessityn proposatutakoak, eta horrexek irekitzen dio bidea N\&Nn egiten den ekarpen berritzaile askori.

Meaning and Necessityn Carnapek operatzaile modalak dauzkaten hizkuntza logiko formaletarako Eredu-Teoria bat garatzen du. Semantika horren oinarria "egoera-deskripzioak" dira, gerora mundu posibletzat ulertu izan denaren halako aurrekari bat: semantika bat eman nahi zaion hizkuntzako proposizio atomiko ororentzat egia-balio bat zehazten du egoera-deskripzio bakoitzak. Beraz, predikatuen logikako hizkuntza batentzat egoera-deskripzio bidezko interpretazio bat daukagunean, hizkuntza horretako edozein $A$ baiezpen hartuta, $A$ egiazkoa izango da egoera-deskripzio batzuetan eta faltsua beste batzuetan (edo egiazkoa egoera-deskripzio guztietan edo faltsua guztietan). Hori horrela, $\square$ eta $\diamond$ operatzaile modalak definitzen ditu Carnapek (berak ez du notazio hori erabiltzen, baina tira), egoera-deskripzioetan oinarrituta. $\square A$ egiazkoa izango da interpretazio batean baldin eta bakarrik baldin $A$ egiazkoa bada interpretazio horretako egoera-deskripzio guztietan - modu bertsuan, $A$ beharrezkoa da interpretazio batean baldin eta bakarrik baldin $A$ egiazkoa bada interpretazio horretako egoera-deskripzio guztie$\tan -$.

Hori Kripkek ez du aldatzen; beno, Kripkek ez ditu mundu posibleak Carnapek egoera-deskripzioak ulertzen dituen modu berean ulertzen, baina Kripkerentzat ere baiezpen bat beharrezkoa izango da baldin eta bakarrik baldin egiazkoa bada mundu posible orotan. Egoera-deskripzio edo mundu posible horiek Carnapek eta Kripkek nola ulertzen dituzten, hor badaude desberdintasunak eta, horrekin, baita beharrezkotasuna bezalako propietate metafisikoak ulertzeko moduan ere (gainontzeko propietate modalekin erlazioan, batez ere). Carnapek Meaning and Necessityn garatzen duen teoria semantikoak izaera intentsionala du. Horrela, $A$ eta $B$ bi predikatu badira, $A \mathrm{k}$ eta $B \mathrm{k}$ intentsio (esanahi) berbera izango dute interpretazio batean baldin eta bakarrik baldin interpretazio horretako egoera-deskripzio orotan estentsio berbera badaukate; eta, $A$ eta $B$ bi baiezpen badira, $A$ k eta $B \mathrm{k}$ intentsio (esanahi) berbera izango dute interpretazio batean baldin eta bakarrik baldin interpretazio horretako egoera-deskripzio orotan egia-balio berbera badaukate. Beraz, $A$ eta $B$ bi baiezpen desberdin beharrezkoak badira interpretazio batean, orduan, Carnapen arabera, intentsio (esanahi) berbera daukate interpretazio horretan eta, are gehiago, intentsio (esanahi) horren oinarrian dira bi baiezpen horiek beharrezkoak. Azkeneko puntu hori garrantzitsua da oso Carnapen moduko neopositibistek egia-modalitate desberdinak nola lantzen

\footnotetext{
${ }^{7}$ Ikus, batez ere, Kripke (1959a, 1959b, 1963).
} 
zituzten ulertzeko, eta horixe da $N \& N n$ Kripkek aldatzen duen puntu garrantzitsu bat - bai, badakit paragrafo honetan auzi konplikatuak oso azkar landu ditudala, baina azkeneko puntu hau da interesatzen zaiguna, eta horri helduko diogu datozen paragrafoetan-.

Izan ere, Kripke baino lehenagoko filosofo (ia) guztien moduan, modalitateen teorian Carnapek onartzen du "ko-estentsio printzipioa" dei genezakeena -Pérez Otero (2006)ren terminologia erabiliz_. Printzipio horren arabera, "beharrezko", "analitiko" eta "a priori" predikatuek estentsio bera daukate (eta berdin "kontingente", "sintetiko" eta "a posteriori"k); alegia, egia bat beharrezkoa da baldin eta bakarrik baldin a priori bada, eta baldin eta bakarrik baldin analitikoa bada. Honela, nahiz eta, lehenago aipatu bezala, modalitate metafisiko, epistemiko eta semantikoen artean bereiz dezakegun, printzipio hori onartzen dutenentzat, azken buruan egiak bi talde handitan bana ditzakegu: alde batetik dauzkagu analitikoak, beharrezkoak eta a priori diren egiak; eta, bestetik, sintetikoak, kontingenteak eta a posteriori diren egiak.

Lehenengoen adibide litzateke "Mutilzaharrak gizonezko ezkongabeak dira", analitikotasunari buruzko eztabaidetan hainbestetan erabilia. Baiezpen hori egiazkoa da, eta egiazkoa da bere esanahiaren oinarrian —analitikoa da-. "Mutilzaharrak", "gizonezko ezkongabeak" eta "dira" hitzen esanahia dena izanik (eta baiezpenaren sintaxia dena izanik), osatzen duten baiezpena egiazkoa da, nolabait esatearren, munduak inongo ekarpenik egin gabe. Behin baiezpenaren esanahia finkatuta, baiezpena egiazkoa da automatikoki, munduak ez du honelakoa edo horrelakoa izan behar baiezpena egiazko egiteko, hori egiazkoa da mundua edonolakoa suertatuta ere. Eta, horregatik, analitikoki egiazkoa izateaz gain, baiezpena beharrezkoa ere bada. Baiezpena ezin zen faltsu izan, behin bere esanahia finkatuta ez baitago baiezpena faltsu egin dezakeen mundu-konfiguraziorik eta, beraz, baiezpena egiazkoa da mundu posible orotan (eta horixe da zerbait beharrezkoa izatea: derrigorrez izatea egiazko). Gainera, baiezpena analitikoa denez, bere esanahiak bakarrik jada egiazko egiten duenez, hiztun konpetente batek jakin dezake baiezpenak dioena egia dela bere konpetentzia linguistikoaren oinarri hutsean, mundua nolakoa den begiratu gabe, "besaulkitik" —alegia, a priori-: baiezpenak dioena egia dela jakiteko ez duzu zertan mutilzaharrak behatzen hasi, horien artean ezkonduta dagoenik badagoen ikusteko.

Bigarren motako egia (sintetikoa, kontingentea eta a posteriori) litzateke, berriz, "Donostiak berrehun mila biztanle baino gutxiago dauzka" baiezpena, adibidez. Baiezpen horrek dioena egia da: baiezpenak esanahi bat dauka, nolabaitekoa izaten deskribatzen du mundua eta, mundua horrelakoa denez, egiazkoa da. Baiezpena osatzen duten hitzek ("Donostiak", "berrehun mila biztanle baino gutxiago" "dauzka") esanahi bat daukate euskaraz eta, baiezpenaren sintaxia tarteko esanahi horiek modu jakin batean konbina- 
tzen direlako, baiezpenak ere esanahi definitu bat dauka euskaraz. Orain, baiezpenaren esanahi hori, bere horretan, ez da nahikoa baiezpena egiazko egiteko; nolabait esatearren, munduak ere egin behar du bere ekarpena baiezpenak dioena egia izan dadin: Donostiak berrehun mila biztanle baino gutxiago badauzka, baiezpena egiazkoa izango da, eta, ez badauzka, faltsua. Alegia, baiezpena ez denez egiazkoa bere esanahiaren oinarri hutsean, ez denez analitikoa, sintetikoa da. Sintetikoa izateaz gain, kontingentea ere bada. Izan ere, baiezpena egiazkoa izan dadin munduak ere egin beharko du bere ekarpena, eta munduak egin dezake ekarpen hori ala ez. Izatez, Donostian berrehun mila pertsona baino gutxiago bizi dira eta, horregatik, baiezpena egiazkoa da. Baina gerta zitekeen mundua desberdina izatea, eta Donostiak berrehun mila biztanle baino gehiago izatea eta, hala gertatu izan balitz, baiezpena faltsua izango litzateke. Baiezpenak dioena egiazkoa delako baina, aldi berean, faltsua izan zitekeelako, baiezpena kontingentea da. Azkenik, baiezpena a priori ez eta a posteriori da egia. Baiezpenak dioena egiazkoa den jakiteko, derrigorrez, mundua nolakoa den begiratu beharko dugu, esperientzia erabili beharko dugu baiezpenak dioena egiazkoa ala faltsua den jakiteko —Donostiako biztanleak kontatu beharko ditugu, adibidez-. Baiezpenak dioena ez da "besaulkiko egia bat", esperientziarik gabe ezagut daitekeen zerbait: a posteriori bakarrik ezagut daitekeen egia bat da.

Carnapentzat (eta beste askorentzat), beraz, egia guztiak bi taldetan bana ditzakegu: alde batetik dauzkagu analitikoak, beharrezkoak eta a priori diren egiak, eta bestetik sintetikoak, kontingenteak eta a posteriori diren egiak; alegia, ezin da egon, adibidez, sintetikoa, a posteriori, baina beharrezkoa den egiarik, edota sintetikoa, kontingentea, baina a priori denik. Aurreko paragrafoak iradokitzen du zergatik den hori horrela: Carnapek (eta beste askok) Pérez Otero (2006)k "beharrezkotasunaren ikuskera semantikoa" deitzen duena onartzen du. Ikuskera honen arabera, analitikotasuna da beharrezkotasunaren eta aprioritasunaren oinarrian dagoena (eta, berdin, sintetikotasuna da kontingentziaren eta aposterioritasunaren oinarrian dagoena). Beharrezkoak diren egiak beharrezkoak dira analitikoak direlako, eta a priori diren egiak $a$ priori dira analitikoak direlako, eta analitikotasuna da beharrezkotasuna eta aprioritasuna azaltzen dituena. Baiezpen bat beharrezkoa izango da bere esanahiak berak zuzenean egiazko egiten duen heinean, hori horrela izanik edozein mundu-konfiguraziok egiazko egingo duelako; eta a priori izango da ezagugarria hiztun konpetente batek bere konpetentzia linguistikoaren oinarri hutsean egia dela ezagut dezakeen heinean, baiezpena ulertzea nahikoa zaionean honek dioena hala dela jakiteko. Eta, garrantzitsuagoa dena: ez dago baiezpen bat beharrezko edo a priori izateko beste modurik.

Ideia hori, beharrezkotasuna eta aprioritasuna analitikotasunean oinarritzen direlako ideia, oso ondo ezkontzen da Carnapen eta beste batzuen jarrera neopositibistarekin. Izan ere, zure proiektu filosofikoaren oinarri nagusietakoa denean ezagutza orok esperientzian egon behar duela oinarri- 
tuta, eta esperientziak esango dizula baiezpen batek dioena gertatzen den ala ez, zaila da ikuskera horretan beharrezkoak eta a priori ezagugarriak diren baiezpenei tartea egitea (eta, arazo handiagoa dena, zaila da beharrezkotzat eta apriorizkotzat jotzen diren matematikaren eta logikaren egiei tartea egitea). Gertakari batzuk ezinbestekoak edota esentzialak direla mantentzeak ireki diezaioke bidea Carnapen kirakoek hainbeste arbuiatzen zuten "metafisika ilunari", eta a priori ezagugarriak diren egiak badaudela esaten baduzu, badirudi konprometitzen ari zarela Vienako enpiristek oso gogoko ez zuten halako razionalismo batekin-edo. Honela, beharrezkotasun eta aprioritasun ororen oinarrian analitikotasuna dagoela aldarrikatuz, egin dakieke tartea mundu-ikuskera neopositibista batean ustez beharrezko eta a priori diren matematikaren, logikaren edota filosofiaren baiezpenei, horiek hizkuntza bat izatearen produktu direla mantenduz, eta arazotsuak izan zitezkeen nozio modal horiek, nolabait esatearren, kontzeptu semantikoen bidez "naturalizatuz".

Ko-estentsio printzipioak eta beharrezkotasunaren nozio semantikoak, beraz, paper garrantzitsua jokatzen dute tradizio neopositibistan, eta guztiz baldintzatzen dute Carnapek eta enparauek modalitateen arteko erlazioak ulertzeko daukaten modua. Noski, jakina da Kripkek N\&Nko hitzaldiak eman zituenerako postulatu neopositibistak bazeudela jada modaz pixka bat pasata —Quine (1951), Austin (1962) edo Kuhn (1962)ren kritikak (oso desberdinak hirurak ere) ez ziren alferrikakoak izan-. Ez ziren gutxi, gainera, kontzeptu modal eta intentsionalekiko jarrera eszeptikoak azaltzen zituztenak. ${ }^{8}$ Halere, modalitateei buruz pentsatzen jarraitzen zutenek onartu ohi zituzten ko-estentsio printzipioa eta beharrezkotasunaren nozio semantikoa, eta halako nozioekiko eszeptiko agertzen zirenek ere ideia horien araberako ikuskerei eraso ohi zieten, gai hauen inguruko hizketa-modu zentzudun posible bakarrak zirelakoan. Kripkek $N \& N n$ ko-estentsio printzipioaren aurka arrazoi onak ematen dituenean, beraz, nozio semantiko eta linguistikoetan oinarritzen ez den beharrezkotasunaren ulerkera berri bat plazaratzen du, "metafisika iluntzat" jotzen ziren ideientzat errespetu filosofikoa irabaziz, garaiko inertzia filosofikoaren kontra.

Kripkek ko-estentsio printzipioari kontradibideak ematen dizkio, eta konbentzigarriki argudiatzen du kontradibideak horixe direla: kontradibideak. Eta, horrekin, beharrezkotasun eta aprioritasun oro analitikotasunean oinarritzen dela ukatzen du, tradizioaren kontra - ko-estentsio printzipioak ikuskera semantikoari jarraitzen baitio, nahitaez-. Hartu, adibidez, izen propioez osatutako identitate-baiezpenak, "Hesperus Phosphorus da" edo "Donostia San Sebastián da" edo "Lewis Carroll Charles Dodgson da" bezalakoak. A posteriori direnez (ezin du inork aurkitu horiek egiazkoak direla be-

${ }^{8}$ Eta hor, noski, Quine da erreferentzia nagusia. Ikus, adibidez, Quine (1953a, 1953b). 
saulkitik altxa gabe), onartu izan da baiezpen horiek kontingenteak diren identitate-erlazioei buruzkoak direla eta, beraz, baiezpenak berak sintetikoak eta kontingenteak direla. Kripkek, berriz, halako baiezpenak, a posteriori izanagatik, beharrezkoak direla argudiatzen du: ${ }^{9}$ modalitate epistemikoaren eta metafisikoaren arteko erlazioa ez da tradizionalki ulertu izan den bezain sinplea, eta modalitate horiek ezin dira beti modalitate semantikoan oinarrituta egon, beraz. Kripkeren argudiaketa bi ideiatan oinarritzen da. Alde batetik, eta Barcan Marcus (1947)ri jarraiki, identitate-erlazio oro beharrezkoa dela dio; bestetik, izen propioak "designatzaile zurrunak" direla —oso azaletik aipatuko ditut horiek hemen-.

Honela dio Barcan Marcusen identitatearen beharrezkotasunaren legeak: $x$ eta $y$ izatez identikoak badira (gauza bera badira), orduan derrigorrez dira identikoak. Hau da:

$$
\forall x y(x=y \rightarrow \square x=y)
$$

Gauza oro da bere buruarekin identiko: predikatuen logika klasikoari identitate-zeinua gehitzen badiogu, identitate-zeinu horren erabilera arautzen duen axioma izango da hori. Teorema bat denez gauza oro bere buruarekin identikoa dela, beharrezkotzearen ${ }^{10}$ arauaren oinarrian, gauza oro bere buruarekin identiko izango da derrigorrez:

$$
\forall x \square(x=x)
$$

Ez dago bere buruarekin identikoa ez den objekturik, eta ezin da egon halakorik. Orain, demagun edozein bi objektu $x$ eta $y$ identikoak direla $(x=y)$. Leibnizen Legeaz, batak duen propietate oro besteak ere izango du, eta $x$-k $x$ rekin derrigorrez identiko izateko propietatea duenez, berdin izango du $y$-k: edozein bi objekturentzat, identikoak badira, orduan derrigorrez dira identikoak. Edo, beste modu batera esanda, identitate-erlazioa beharrezkoa da.

Identitatearen beharrezkotasunaren ideia ez da berria, Barcan Marcusek lehenago proposatu zuelako, baina ez zuen onarpen zabalik lortu filosofia akademikoan. Izan ere, "Hesperus Phosphorus da" bezalako identitate-baiezpenek, a posteriori direlako, kontingenteak dirudite (Hesperus Phosphorus dela aurkitu genuen, baina erraz imajina dezakegu gauzak desberdin suertatu zirela, mundu posibleren batean Hesperus ez dela Phosphorus aurkitu genuela). Beraz, baiezten dituzten identitate-erlazioek ere kontingenteak izan beharko dute. Eta hor laguntzen du Kripkek eztabaida hauetan argi pixka bat sartzen.

\footnotetext{
${ }^{9}$ N\&Nn Kripkek ez dio askorik analitikotasunari eta sintetikotasunari buruz. Badirudi onartzen duela egia bat analitikoa bada orduan beharrezkoa eta a priori izango dela derrigorrez. Alegia, Kripkeren beharrezko $a$ posterioriak eta a priori kontingenteak egia sintetikoak lirateke.

${ }^{10}$ Necessitation, ingelesez.
} 
Kripkek onartzen du Barcan Marcusen identitatearen beharrezkotasunaren legea, eta horri eusten dio: ez dago, beraz, kontingentea den identitate-erlaziorik, nahiz eta filosofo batzuek horrelakorik esan. Beste gauza bat da identitate-baiezpenak beharrezkoak ala kontingenteak diren: agian onar dezakegu "ILCLI institutua dagoen hiria Gipuzkoako hiriburua da" baiezpenak identitate-erlazio bat deskribatzen duela; baina baiezpen hori, zalantzarik gabe, kontingentea da (bazitekeelako ILCLI ez egotea Donostian, edota Donostia ez izatea Gipuzkoako hiriburua). Nolanahi ere, onartzen badugu baiezpen horrek objektu batek bere buruarekin daukan identitate-erlazio bat deskribatzen duela, orduan, identitate-erlazio hori, hori bai, beharrezkoa da (ezin baita objektu hori existitu bere buruarekin identikoa izan gabe). Orain, parte interesgarriena hemen dator: nahiz eta badauden kontingenteak diren identitate-baiezpenak, N\&Nko irakasgai garrantzitsuenetakoa da izen propioez osatutako identitate-baiezpenak bai direla beharrezkoak (nahiz eta, agian, a posteriori bakarrik diren ezagugarriak).

Hori horrela da izen propioak ("Donostia", "Kripke", "Hesperus", "Ekain") designatzaile zurrunak direlako —esango dut zerbait (gutxi) horiei buruz paragrafo batzuk beherago- - Har dezagun Kripkek berak darabilen adibidea: "Hesperus Phosphorus da" identitate-baiezpena. "Hesperus" eta "Phosphorus", izen propioak izanik, designatzaile zurrunak dira. Designatzaile zurrunak mundu posible orotan objektu bera designatzen duten designatzaileak dira, definizioz. Adibidez, "Gipuzkoako hiriburua" designatzailea da, baina ez designatzaile zurruna. Balio digu unibertsoko objektuetatik bat "hautatzeko" (Gipuzkoako hiriburua den objektu hori; izatez, Donostia), baina mundu posible desberdinetan objektu desberdinak designatzen ditu. Adibidez, mundu errealean Donostia designatzen du, Donostia baita Gipuzkoako hiriburua. Baina demagun beste mundu batean ez dela Donostia Gipuzkoako hiriburua, Anoeta baizik. Mundu horretan "Gipuzkoako hiriburua" designatzaileak ez du Donostia designatuko, Anoeta baizik, eta "Gipuzkoako hiriburua Tolosa ondoan dago" baiezpena, adibidez, egiazkoa izango da. "Gipuzkoako hiriburua" gisako deskripzioak ez dira designatzaile zurrunak. Orain, Kripkek argudiatzen duenez, izen propioak badira designatzaile zurrunak. Har dezagun "Kripke" izen propioa. Erabil dezakegu izen propio hori mundu posibleak deskribatzeko. Deskriba dezakegu mundu bat non Kripke ez den filosofoa, edo mundu bat non Kripke Errusian jaio den, hartarako "Kripke" izen propioa erabiliz. Kontua da, mundu posible bat deskribatzeko "Kripke" izen propioa erabiltzen dugun bakoitzean, izen hori erabiltzen dugula Kripke, objektu hori, designatzeko: nik esaten badizut "Kripke halakoa-eta-halakoa izan balitz..." edo "Kripkeri halakoak-eta-halakoak gertatu izan balitzaizkio...", Kripkeri buruz ariko naiz, objektu horri berari buruz.

Izen propioak designatzaile zurrunak dira, beraz: izen propio batek objektu berbera designatzen du mundu posible orotan. Baina hori horrela bada, dio Kripkek, orduan izen propioez osatutako identitate-baiezpenak beharrezkoak dira egiazkoak badira. Hartu, adibidez, "Hesperus Phosphorus da". Baiezpen hori egiazkoa bada (eta bada), orduan derrigorrez da egiazkoa: 
beharrezkoa da. Baiezpena egiazkoa da, Hesperus Phosphorus da, eta, beraz, bi izen propio horiek objektu bera designatzen dute mundu honetan-Artizarra, bide batez-. Orain, "Hesperus" izen propioak Artizarra designatzen badu, designatzaile zurruna den heinean, Artizarra designatuko du mundu posible orotan —eta berdin gertatuko da "Phosphorus" izen propioarekin, Artizarra designatuko du mundu posible orotan-. Beraz, "Hesperus" izenak objekturen bat designatzen badu $w$ mundu posiblean, objektu hori Artizarra izango da, eta "Phosphorus" izenak objekturen bat designatzen badu $w$ mundu horretan, objektu hori ere Artizarra izango da, eta egia izango da $w$ mundu horretan Hesperus Phosphorus dela: ez dago "Hesperus Phosphorus da" baiezpena faltsu egiten duen mundu posiblerik. Pentsatu izan denaren kontra, izen propioez osatutako "Hesperus Phosphorus da" gisako identitatebaiezpenak beharrezkoak dira egiazkoak badira, eta inoiz ez kontingenteak.

Dena den, baiezpenak kontingentea dirudi, eta kontingentea dela onartu dute gai hauei buruz hausnartu duten ia filosofo guztiek. Bai, kontingentea dirudi, baina beharrezkoa da —edo horrela dio behintzat Kripkek-. Eta kontingentea dirudi beharrezkoa izanik ere a posteriori delako, eta ez a priori. "Hesperus" eta "Phosphorus" izen propioak modu arruntean ikasi dituen inork ez du jakingo Hesperus Phosphorus dela, ez badu horren aldeko ebidentzia enpirikorik lortzen; ez da besaulkitik ezagut daitekeen zerbait, asko eta oso ondo pentsatuta ere. A posteriori delako, ezin dugunez arrazoiketa hutsez jakin egia ala faltsua den, iruditzen zaigu izan daitekeela egia edo faltsua, baina ez da horrela. "Hesperus Phosphorus da" gisako identitate-baiezpenak beharrezkoak dira, baina a posteriori, eta a posteriori direlako iruditzen zaigu kontingenteak direla (baina, berriz: ez dira, ezin dira izan). ${ }^{11}$

Beharrezkoak eta a posteriori diren egiez gain, Kripkeren iritziz badaude kontingenteak baina a priori ezagugarriak diren egiak ere. Kontradibide ezagun bat ematen du Kripkek, Pariseko metro estandarrarena (norbaitek metro estandarra hartu eta "honek metro bat neurtzen du" esaten du), baina iruditzen zait "izen deskriptiboak" erabiltzen dituzten adibideak argiagoak direla. Adibidez, badago oraintxe bertan, errusiarren artean, denetan altuena den norbait. Dei diezaiogun, zergatik ez, "Vladimir". ${ }^{12}$ Aurrena, Vladimir existitzen da, errusiarrak badira, eta norbaitek izan beharko du errusiarren artean altuena. Eta hitz egin dezakegu tipo horri buruz, errusiarren artean altuena den tipoari buruz, "Vladimir" izena erabiliz, konbentzio bidez oraintxe hala erabaki dugulako. Honela, galde diezaiokegu geure buruari ea Vladimir moskutarra izango den edota Errusia Ekialdeko estepan jaiotako gizasemea; pen-

\footnotetext{
11 Halako baiezpenen "kontingentzia-itxura"ri buruz, ikus ale honetan itzuli dugun N\&Nko bigarren hitzaldiko azken pasarteak (57-59 orrialdeak).

12 N\&Nn Kripkek "Jack tripa-ateratzailea" jartzen du izen deskriptiboen adibide gisa (ikus ale honetako 41 orrialdea); beste adibide ezagun bat da Evans (1979)ren "Julius", kremailera asmatu zuen pertsona.
} 
tsa dezakegu errusiera dela, ziur asko, Vladimirren ama-hizkuntza (hala gertatzen baita errusiar gehienekin); eta nahiko ziur egon gaitezke Vladimir izango dela, gutxienez, bi metro luze (bai baitakigu badirela bi metro luze edo gehiago diren errusiarrak, eta Vladimir errusiarren artean altuena denez, bada...). Har dezagun orain "Vladimir da errusiarrik altuena" baiezpena. Badakigu egia dela, definizioz: errusiarrik altuena Vladimir edo beste norbait den jakiteko ez dugu errusiarrak neurtzen hasi beharrik; errusiar altuenari "Vladimir" deitzea erabaki dugunez, badakigu, "besaulkitik altxa gabe", Vladimir dela errusiarrik altuena. Alegia, baiezpena a priori da ezagugarria Kripkeren iritziz, ez baitugu ebidentzia enpirikorik behar baiezpen hori egia dela jakiteko. Orain, Kripkeren iritziz hau ere, baiezpena kontingentea da. Vladimir da, izatez, errusiarrik altuena, baina izan zitekeen bestela. Vladimir dena baino baxuagoa balitz (hori gerta zitekeen), edota Vladimir baino altuagoa den beste errusiarren bat egongo balitz, orduan, Vladimir, tipo hori, ez litzateke errusiarrik altuena izango. Alegia, nahiz eta Vladimir den errusiarrik altuena mundu errealean, badaude mundu posibleak non Vladimir ez den errusiarrik altuena, non "Vladimir da errusiarrik altuena" faltsua den eta, beraz, baiezpena ez da beharrezkoa eta kontingentea da. Horrelako baiezpenak, beraz, kontingenteak dira Kripkeren iritziz, baina a priori ezagugarriak. ${ }^{13}$

13 Egon da eztabaidarik (asko) Kripkeren beharrezko $a$ posteriorien eta kontingente $a$ priorien inguruan, baina bi kasuetan eztabaidak desberdinak izan direla esango nuke. Esango nuke filosofo gehienek onartu dutela Kripkek emandako adibide batzuk badirela beharrezko a posterioriak, eta horien inguruan sortu diren eztabaida gehienen helburua beharrezko a posteriori horien izaera azaltzea izan dela. Zalantza handiagoak egon dira, nire ustez, Kripkeren kontingente $a$ priorien inguruan (nahiz eta metafisikaren aldetik ez diren beharrezko $a$ posterioriak bezain interesgarriak). Filosofo askok ez dituzte Kripkeren adibideak onartzen: ez dute uste ezagutza hain erraz "sortu" dezakegunik, konbentzio linguistiko baten bitartez (horrelako eztabaiden inguruan, ikus, adibidez, Donnellan (1977), Evans (1979) edo Jeshion (2010)en bildutako artikuluak). Gainera, badirudi Kripkek berak ere bazeuzkala zalantzak eman zituen a priori kontingenteen adibideek ustez erakusten dutenari buruz:

Norbaitek metro bat zehazten badu "S barraren luzera $\mathrm{t}_{0}-\mathrm{n}$ " bezala, orduan zentzuren batean a priori daki S barraren luzera $\mathrm{t}_{0}-\mathrm{n}$ metro batekoa dela, nahiz eta baiezpen hori erabiltzen duen egia kontingente bat adierazteko. Baina, neurtze-sistema bat ezartzeagatik bakarrik, ikasi al du horrela informazio (kontingente)rik munduari buruz, lehenago ezagutzen ez zuen gertakari berririk? Onargarria dirudi zentzuren batean ez duela halakorik egin, nahiz eta ezin den ukatu gertakari kontingente bat dela S-k metro bat neurtzen duela Egon daitezke motiboak, beraz, a priori den oro beharrezkoa delako tesia birformulatzeko, hori mota honetako kontradibideetatik libratzeko asmoz. Esan dudan moduan, ez dakit nolakoa izango litzatekeen halako birformulaketa bat. (Kripke 1980: 63, 26 oin-oharra)

[If someone fixes a meter as "the length of stick $S$ at $t_{0}$ ", then in some sense he knows $a$ priori that the length of stick $S$ at $t_{0}$ is one meter, even though he uses this statement to express a contingent truth. But, merely by fixing a system of measurement, has he thereby learned some (contingent) information about the world, some new fact that he did not know before? It seems plausible that in some sense he did not, even though it is undeniably a contingent fact that $\mathrm{S}$ is one meter long. So there may be a case for reformulating the thesis that everything a priori is necessary so as to save it from this type of counterexample. As I said, I don't know how such a reformulation would go.] 
Badaude, beraz, beharrezkoak izanik a posteriori diren egiak, eta baita kontingenteak izanik a priori direnak ere, eta egia-modalitateen arteko erlazioak ez dira tradizionalki pentsatu izan dena bezain sinpleak (ezin ditugu egia guztiak bi taldetan banatu). Eta, hori baino garrantzitsuagoa dena, ko -estentsio printzipioa beharrezkotasunaren ikuskera semantikoaren ondorio zuzena denez, behin ko-estentsio printzipioa ukatuta ikuskera semantikoa ere ukatu egin beharko dugu. Alegia: ez da analitikotasuna beharrezkotasun ororen eta aprioritasun ororen oinarrian egongo dena, eta analitikotasuna azaltzen duten nozio semantikoek ez dute zertan balio baiezpen baten beharrezkotasuna edota aprioritasuna azaltzeko — goian erabili ditudan bi adibideak, "Hesperus Phosphorus da" eta "Vladimir da errusiarrik altuena", sintetikoak dira, nahiz eta lehena beharrezkoa den eta bigarrena a priori-. Kripkeren kontradibideek, beraz, bidea irekitzen diote gai hauek ulertzeko modu berri bati: bere kontradibideak onartzen baditugu, lekua egin beharko diegu nozio semantiko hutsen bitartez azaldu ezingo ditugun baiezpen beharrezkoei —neopositibistek arbuiatzen zuten "metafisika ilun" hori ate-joka datorkigu-. N\&Nn praktikan jartzen da gai horietara gerturatzeko modu eta estilo berri bat, zuzenean eragiten diona munduaz eta bere ezagutzaz daukagun oinarrizko ikuskerari: ziur asko, horixe da $N \& N k$ filosofiari egin dion ekarpen nagusietakoa.

\section{Mundu posibleak eta designatzaile zurrunak}

$N \& N n$, beraz, modalitateen arteko erlazioari eta beharrezkotasunari eta aprioritasunari begiratzeko modu berri bat aurkitzen dugu. Horiei forma emateko, argi azaltzeko, eta horien alde argudiatzeko, Kripkek erreminta modal berriak erabiltzen ditu bere hitzaldietan, auzi hauetaz aritzeko modu berri bat dakartenak. Horiekin, gainera, logika modalari buruz eta horren filosofiari buruz ohikoak ziren zalantza eta ardura batzuei errazago erantzutea lortzen du. Azal dezadan hori orain, labur bada ere.

Kripkek N\&Nko hitzaldiak eman zituenerako, logika modal formalek jada bazeukaten historia txiki bat. Russell eta Whiteheadek Principia Mathematica argitaratu eta zortzi urtera bakarrik, horiek baldintza materialari eman zioten tratamenduarekin desados, CI Lewisek baldintza zorrotza operatzaile moduan darabilen sistema proposatu zuen; urteen buruan, operatzaile modalak darabiltzaten sistema axiomatikoak ere garatu zituen. 1940ko hamarkadan, Barcan Marcusek aurrerapen handiak egin zituen operatzaile modalak zenbatzaileen logikarekin konbinatzeko, operatzaile horiek formula irekiei eragitea posible eginez, eta teorema eta arau ugari aztertuz. Urte berberetan, Carnapek semantika formal intentsionalak garatu zituen, besteak beste operatzaile modalak darabiltzaten hizkuntza formalentzat proposatzeko asmoz. 1950eko hamarkada bukaeratik aurrera, Kangerrek, Hintikkak, Kripkek eta beste batzuek aurrerapen handiak egin zituzten, mundu posibleetan oinarritutako 
semantikak garatuz eta hainbat sistema axiomatikoren osotasun- eta zuzentasun-frogak emanez. ${ }^{14}$ Historia horri paraleloki, badago logika horiekiko eta horien filosofia eta ondorioekiko mesfidatia den tradizio bat. Eta Quine da "eszeptizismo modal" horren ordezkari nagusia.

Quineren arabera, logika modalek zentzugabekerietara garamatzate, batez ere horientzat semantikak garatzen hasten garenean, eta guztiz iluna den eta jada alboratua zegoen halako metafisika aristoteliko esentzialista batera eraman gaitzakete. ${ }^{15} \mathrm{Hartu}$, adibidez, honako bi baiezpen modalak:

(1) 9 derrigorrez 7 baino handiagoa da. [Edo: $\square(9>7)$ ]

(2) Planeta kopurua derrigorrez 7 baino handiagoa da. [Edo: $\square$ (planeta kopurua > 7)]

Noski, (1) egiazkoa da, eta (2) faltsua. Edo hala esango lukete behintzat nozio modalak erabiltzen dituen diskurtsoa zentzuduna dela dioten logikari modal eta filosofo guztiek -Quineren moduko eszeptiko modal batentzat, "derrigorrez" gisako adierazpenek ez daukate zentzurik (horiekin beharrezkotasun metafisiko bati buruz-edo ari bagara, behintzat), eta $\square$-ren moduko operatzaileak dauzkaten hizkuntzak ilunak dira, kasurik onenean-. Orain, denok dakigun moduan:

\section{(3) 9 = planeta kopurua ${ }^{16}$}

Jakina denez, Leibnizen Legearen arabera, $a$ eta $b$ identikoak badira, orduan $a \mathrm{k}$ P propietate bat dauka baldin eta bakarrik baldin $b \mathrm{k} \mathrm{P}$ propietate hori badauka eta, horregatik, badirudi objektu bera erreferitzen duten " $a$ " eta " $b$ " zeinuek salva veritate ordezkagarriak izan beharko dutela. Orain, hartu (1) baiezpena, askok egiazkotzat dutena. (3) ere egiazkoa denez, Leibnizen Legearen oinarrian, bada, (1)en "9"k duen agerpena "planeta kopurua" adierazpenaren agerpen batekin ordezka genezake, baiezpen horren egia-balioan eragin gabe. Baina horrela lortzen dugun baiezpena (2) da, eta (2) faltsua da (horretan uste dut denok ados gaudela).

Adierazpen ko-erreferenteen salva veritate ordezkapenaren printzipioa ez da betetzen testuinguru modaletan, beraz, eta, Quineren arabera, horrek era-

\footnotetext{
14 Ikus, adibidez: Lewis (1918), Lewis eta Langford (1932), Barcan Marcus (1946, 1947, 1961), Carnap (1947), Kanger (1957), Hintikka (1963) eta Kripke (1959a, 1959b, 1963).

15 Hemendik aurrerakoak, batez ere, Quine (1953a)n garatzen dira; baina ikus, baita ere, Quine (1947, 1953b).

16 Edo hala zen behintzat Quinek bere artikuluak idatzi zituen garaian. Geroztik Plutonek planeta-estatusa galdu du, eta lerro hauek idazten ari naizen momentuan zortzi planeta daude eguzki-sisteman —egia da, baita ere, Plutoni planeta-ziurtagiria itzul diezaioten eskatzen ari direla astronomo batzuk, eta zeinek jakin lerrook irakurtzen diren momentuan zenbat izango diren eguzki-sisteman jiraka ariko diren planetak-.
} 
kusten du horrelako testuinguruak ilunak direla, kasurik onenean, eta zentzugabekeria hutsak, ziur asko. Izan ere, aplika diezaiokegu zenbatzaile existentzialaren orokortze-araua (1)i:

\section{(4) $\exists x(x$ derrigorrez 7 baino handiagoa da)}

Eta, beraz, badago zerbait derrigorrez 7 baino handiagoa dena. Hori, derrigorrez 7 baino handiagoa den gauza hori, 9 da: alegia, planeta kopurua. Nolanahi ere, nahiz eta 9 derrigorrez 7 baino handiagoa izan, planeta kopurua ez da derrigorrez 7 baino handiagoa. Alegia, badagoela objektu bat geure munduan, hari deitzeko aukeratzen dugun adierazpen-formaren arabera propietate modal bat izango duena ala ez. Zentzugabekeria hutsa da (Quineren iritziz): objektuek dauzkaten propietateak dauzkate, horiei buruz hitz egiteko erabiltzen ditugun adierazpenez independenteki. Eta, agian, dio Quinek, saia gaitezke arazoari iskin egiten, gauzak izendatzeko erabil ditzakegun adierazpenen artean mailaketak eginez. Horrela, adibidez, egongo litzateke objektu bat derrigorrez 7 baino handiagoa dena; gertatzen dena da objektu horri deitzeko modu batzuek (" $3^{2}$ ", adibidez) beste batzuek ("planeta kopurua") baino hobeto islatzen dutela objektuaren "esentzia". Lehenengoek objektuaren esentzia erakusten dutenez, erabil ditzakegu horiek objektuak propietate batzuk derrigorrez dituela egiazki esateko. Baina hori, berriz, kasurik okerrenean zentzugabekeria ulergaitza da eta, kasurik onenean, metafisika esentzialista aristoteliko iluna, garaiko zientziarekiko ikuspegiekin bateraezina, aspaldi atzean utzia zegoena (Quineren iritziz).

Quineren kexek jaso zituzten erantzunak, ${ }^{17}$ baina, ziur asko, Kripkek eman zituen azalpen argienak, $N \& N n$. Hitzaldietan, dagoeneko aipatu dudan "designatzaile zurrun" kontzeptua erabiltzen du lehenengo aldiz, eta horrek balio dio auzi hauetan ordena pixka bat jartzeko, eta auzi modalei buruz aritzeko modu eta estilo berriei bidea irekitzeko.

Lehenago aipatu dudanez, designatzaile zurrun bat mundu posible orotan objektu bat eta berbera designatzen duen adierazpen mota da. Badaude adierazpen batzuk objektuak designatzeko balio dutenak; horiek "hautatzeko" balio dutenak, nolabait esatearren. Deskripzio definituak, erakusleak, indexikoak eta izen propioak, adibidez, designatzaileak dira: horiek erabiliz objektu bat designa dezakegu, gero horri buruz zerbait predikatzeko, adibidez. Designatzaile batek designatzen duen objektua alda daiteke mundutik mundura. Deskripzio definitu gehienek, adibidez, objektu desberdinak designatzen dituzte mundu posible desberdinetan eta, beraz, designatzaile ez-zurrunak dira. Hartu, esaterako, "Kripkek gehien miresten duen filosofoa" deskripzioa, eta demagun Ruth Barcan Marcus dela, izatez,

17 Ikus Barcan Marcus (1961, 1990). 
Kripkek gehien miresten duen filosofoa. Hori egiaz hala bada, mundu honetan, mundu errealean, "Kripkek gehien miresten duen filosofoa" deskripzioak Barcan Marcus designatuko du, eta "Kripkek gehien miresten duen filosofoa estatubatuarra da" baiezpenak dioena egia izango da. Baina har dezagun beste mundu posible bat, eta demagun mundu horretan Kripkeren filia filosofikoak desberdinak direla oso, moda postestrukturalistei men egin dielako-edo. Mundu bitxi horretan ez da Barcan Marcus Kripkeren filosofo gogokoena, baizik eta Michel Foucault, eta azken hori designatzen du "Kripkek gehien miresten duen filosofoa" deskripzioak. Horrela, "Kripkek gehien miresten duen filosofoa estatubatuarra da" baiezpenak dioena faltsua da mundu horretan. Ez da zaila.

Baina badaude zurrunki designatzen duten designatzaileak ere, mundu posible orotan objektu berbera designatzen dutenak. Hala gertatzen da deskripzio definitu batzuekin, objekturen baten propietate esentzialen bat esplotatzen dutenean designatzeko ("9ren erro karratua" deskripzioak, adibidez, 3 zenbakia designatzen du mundu posible orotan); baina indexiko, erakusle eta izen propioak adibide argiagoak dira. Hartu, adibidez, "Ruth Barcan Marcus" izen propioa. Designatzaile bat da, objektu bat designatzeko erabil dezakegulako, Barcan Marcus. Eta hartu "Ruth Barcan Marcus estatubatuarra da" baiezpena: Barcan Marcus estatubatuarra denez, baiezpen horrek dioena egia da mundu honetan, mundu errealean. Noski, erabil dezakegu "Ruth Barcan Marcus" beste mundu posible bateko objekturen bat designatzeko. Kontua da begi-bistakoa dirudiela izen horrek objektu berbera (Barcan Marcus) designatuko duela mundu posible orotan: nik eskatzen badizut irudikatzeko Ruth Barcan Marcus poloniarra den mundu bat, edo frantziarra den mundu bat, edo euskalduna dena edo korearra, Barcan Marcus designatzen ari naiz mundu horietan guztietan (objektu hori berbera). Beraz, "Ruth Barcan Marcus" izena designatzaile zurruna da. Barcan Marcusek beste hiritartasun bat ere izan zezakeenez, "Ruth Barcan Marcus estatubatuarra da" baiezpenak dioena faltsua izango da Barcan Marcus poloniarra, frantziarra, euskalduna edo korearra den mundu horietan. Hau ere ez da zaila.

Designatzaile batzuek zurrunki eta beste batzuek ez-zurrunki designatzen dutela kontuan hartzen badugu, erraz askatzen dira Quine hainbeste arduratzen zuten korapiloak eta ustezko zentzugabekeriak. Goian ikusi dugunez, Kripkek gehien miresten duen filosofoa Ruth Barcan Marcus da (identikoak dira bi pertsona horiek), eta berau estatubatuarra da, baina badaude mundu posibleak non "Ruth Barcan Marcus estatubatuarra da" baiezpenak dioena egiazkoa den eta "Kripkek gehien miresten duen filosofoa estatubatuarra da" baiezpenak dioena, faltsua (eta alderantziz), eta hori ez da inolaz ere arazo, ez Leibnizen Legearentzat, ez adierazpen ko-erreferenteen salva veritate ordezkagarritasunarentzat. Bada, gauza bera gertatzen da Quineren zenbaki eta planetekin. Quineren ustezko puzzlea askatzeko 
giltza da konturatzea "9" designatzaile zurruna dela eta "planeta kopurua", aldiz, designatzaile ez-zurruna. Quinek ondo zioen moduan, badago objektu bat, bederatzi zenbakia, derrigorrez zazpi baino handiagoa dena, existitzen den mundu posible orotan zazpi baino handiagoa baita (bai, konplikaziotan sartu nahi gabe, emantzat jotzen ari naiz zenbakiak existitzen direla eta, gainera, mundu posible guztietan existitzen direla, eztabaida hauetan jo ohi den moduan). Objektu hori mundu errealean designatzeko, erabil ditzakegu designatzaile zurrunak ("9") edo ez zurrunak ("eguzki-sistemako planeta kopurua"). Designatzaile zurrun bat erabiltzen badugu, gero zazpi baino handiagoa dela esateko, beraz, mundu posible orotan egia den zerbait esango dugu, derrigorrezkoa den zerbait. Designatzaile ez-zurrun bat erabiltzen badugu, gero zazpi baino handiagoa dela esateko, berriz, mundu batzuetan egiazkoa eta beste batzuetan faltsua den zerbait esango dugu, designatzaile ez-zurrun horrek mundu batzuetan zazpi baino txikiagoak diren zenbakiak designatzen baititu. Alegia: "9" zurruna denez, mundu posible orotan 9 zenbakia designatzen du, eta, mundu posible orotan 97 baino handiagoa denez, "9 7 baino handiagoa da" egia da mundu posible orotan edo, bestela esanda, "9 derrigorrez 7 baino handiagoa da" egiazkoa da. Bestalde, "planeta kopurua" ez-zurruna denez, 9 zenbakia designatzen du mundu errealean, baina 4 zenbakia eguzki-sisteman lau planeta dauden mundu batean, edo 0 eguzki-sisteman planetarik ez dagoen mundu batean, edo 134 eguzki-sisteman hainbeste planeta dauden mundu batean, eta, beraz, "Planeta kopurua 7 baino handiagoa da" egiazkoa izango da mundu horietako batzuetan (tartean, mundu errealean) eta faltsua beste batzuetan, eta, horrenbestez, "Planeta kopurua derrigorrez 7 baino handiagoa da" faltsua da. Eta hau ere ez da zaila (tira, agian pixka bat bai).

Designatzaile zurrunen eta ez-zurrunen arteko desberdintasuna aintzat hartzen badugu, erraza da ikusten nola izan daitekeen (1) egiazkoa eta (2) faltsua, nahiz eta (3) ere egiazkoa den, eta ez zaigun arazorik edo zentzugabekeriarik agertzen inon. Egia da, akaso, halako esentzialismo aristotelikoren batekin konprometitu beharko dugula, 9 zenbakiari "zazpi baino handiagoa izatea" propietate esentziala zaiola esan beharko baitugu, eta "eguzki-sistemako planeta kopurua izatea" propietate kontingentea zaiola. Baina Kripkek ez dauka horrelako ondorioak onartzeko inolako arazorik eta, erabiltzen dituen erreminta modal berriek ematen dizkiguten azalpenei esker, "metafisika aristoteliko iluna" baino "metafisika aristoteliko argixeagoa" dela erantzun dakioke Quineri.18

Eta badago hemen lotura bat errelebantea dena azaldu nahi ditudanak hobeto ulertzeko, alegia, Kripkek erabiltzen dituen erreminta berriek bide

18 Esentzialismo aristotelikoaren, klase-esentzialismoaren eta esentzialismo indibidualaren inguruan, ikus ale honetan bertan aurki daitekeen Michael Devitten artikulua. 
berriak irekitzen dituztela fenomeno modalak ulertu eta lantzeko. Designatzaile zurrunen nozioa bera lotuta dago mundu posibleak ulertzeko modu partikular batekin:

...mundu posible bat zer den gaizki planteatzen delako da hori. Eredu
horretan, mundu posibleak hartzen dira atzerriko herrialde bat izango
balira bezala. Horiei begiratzen diegu behatzaileak izango bagina bezala.
(...) kualitateak bakarrik ematen zaizkigu. (...) Nolanahi ere, intuitiboki
hitz eginez, iruditzen zait ez dela mundu posibleei buruz pentsatzeko
modu egokia. Mundu posible bat ez da urrun dagoen herrialde bat, ber-
tara iristen ari garena, edo teleskopio baten bitartez ikusten ari garena.
(...) Mundu posible bat harekin lotzen ditugun baldintza deskriptiboen bidez
ematen da. (...) "Mundu posibleak" estipulatu egiten dira, ez dira telesko-
pio indartsu baten bitartez aurkitzen. (Kripke 1980: $43-44)^{19}$

Mundu posibleak ez dira "aurkitzen" ditugun gauzak, "estipulatzen" ditugun gauzak baizik. Mundu posible bat ez da teleskopio baten bidez ikus dezakezun zerbaiten modukoa. Alegia, mundu posible bat ez da "kualitatiboki" aurkezten zaigun zerbait; mundu posibleak ez dira hautematen ditugun gauzak, mundu posible bat "arakatzen" ari garenean ez ditugu mundu horren propietate edo kualitateak hautematen, itxura kualitatibo horren atzean dagoenaren izaera aurkitu edo inferitu behar dugun zerbait izanik. Horrela litzateke, adibidez, mundu posibleak teleskopioen bitartez ikus ditzakegun planeta urrunen gisakok balira. Planeten kasuan, horien ezaugarri batzuk hautematen ditugu, horien kualitateak. Horrela, teleskopio batetik begiratzen dugunean ikus dezakegu, adibidez, planeta jakin batean badagoela gardena den likido bat, edo badaudela marra hori-beltzak dauzkaten katu antzeko animalia handiak, edo badagoela tipo burusoil bat; orain, kualitate horien atzean dagoena ura ote den, edo tigreak ote diren, edo Michel Foucault ote den, hori aurkitu edo inferitu behar dugun zerbait da. Baina mundu posibleak ez dira urruneko planetak bezalakoak, ez ditugu hautematen. Mundu posibleak estipulatu egiten ditugun entitateak dira, eta estipulazio horiek egiterakoan ez dugu zertan guztiz kualitatiboa denean geratu: erabaki dezakegu, adibidez, mundu posible batean Foucault eta bi tigre bainu bat hartzen ari direla urez betetako igerileku batean. Bainua hartzen ari dena Foucault dela (eta ez bere antza duen norbait) eta igerilekua urez beteta dagoela (eta ez gardena den beste likido batez) estipula ditzakegun gauzak dira, eta horrelakoak estipulatzeko modurik errazena "Foucault" eta "ura" gisako designatzaile zu-

\footnotetext{
19 [...this depends on the wrong way of looking at what a possible world is. One thinks, in this picture, of a possible world as if it were like a foreign country. One looks upon it as an observer. (...) one is given only qualities. (...) Nevertheless, intuitively speaking, it seems to me not to be the right way of thinking about the possible worlds. A possible world isn't a distant country that we are coming across, or viewing through a telescope. (...) A possible world is given by the descriptive conditions we associate with it. (...) "Possible worlds" are stipulated, not discovered by powerful telescopes.]
} 
rrunak erabiltzea da. Horrelako adierazpenak designatzaile zurrunak direlako ideia eta horiek oinarrian daukaten designazio-mekanismoa, beraz, lotuta daude mundu posibleen izaera ulertzeko modu batekin —mundu posibleak estipulatzen ditugun entitateak dira-

Beraz, labur, N\&Nn Kripkek sartzen ditu erreminta modal eta kontzeptual berriak, eta lehendik eskura zeuden nozio eta erreminta batzuk modu berrian erabiltzen ditu. Horiek plaza edo joko-zelai filosofiko berri eta txukunagoa osatzen dute. Horrela, errazagoa da, argiago zedarritutako joko-zelai horretan, ilunak ziruditen auziak planteatu eta argitzea; hala gertatzen da, adibidez, Quineren zenbaki, planeta eta susmoekin. Eta, modu bertsuan, plaza berri bat daukagu auzi modal, metafisiko eta metasemantiko berriak planteatzeko, edo auzi zaharrak estilo argiagoan eta berritzailean planteatzeko; hala gertatzen da, adibidez, ale honetarako itzuli dugun bigarren hitzaldian Kripkek erreferentziaren inguruko auziak eztabaidatzen dituenean, edo hirugarren hitzaldian Gogoaren Filosofian argudio anti-materialista zahar bat biziberritzen duenean. Azken horri buruz ariko naiz hurrengo atalean.

\section{Minak, gorputzak eta designatzaile zurrunak}

Kripke anti-materialista da, dualista, gogo-gorputz erlazioari dagokionez —eztabaida eta posizio horiek zaharrak eta ezagunak dira literatura filosofikoan-. Pentsa sentsazioren batean: pentsa min handiren batean, adibidez, ze min mota sentitzen duzun eskua sutan jartzean, edo migraina gogorra daukazunean; edo pentsa nola sentitzen diren hotza eta gosea; edo nola sentitzen den kolore bat ikustea, gorri bizi bat, adibidez. Horiek denak gertatzen zaizkizunean gorputz-egoera batean egongo zara eta, zehatzago, zure garuna edo zure nerbio-sistema osoa egoera partikular batean egongo da. Jakina denez, filosofiari aspalditik interesatzen zaion auzia da ea zein den egoera mota horien arteko erlazioa: ze erlazio mota dagoen sentitzen duzun min baten eta min hori sentitzerakoan zauden gorputz-egoeraren edota garunaren edo nerbiosistemaren egoeraren artean. Esan dezakezu bi gauza desberdin daudela hor, gauza bat dela mina eta beste bat mina sentitzean daukazun garun-egoera; edo esan dezakezu egoera bakarra dagoela, mina eta garun-egoera gauza bat eta berbera direla; edo esan dezakezu, nahiz eta gauza bakarra dagoen hor, garuna alegia, mina eta garunaren egoera fisikoa garunak dauzkan bi propietate desberdin direla eta, agian, bi propietate horien artean badagoela erlazio bereziren bat. Mende batzuk atzera egiten badugu, adibidez, Descartesek esaten zuen gogoa eta gorputz materiala bi substantzia metafisiko desberdin zirela (izaera oso desberdineko bi gauza), eta bazeuzkan arazoak horien artean dauden erlazio kausalak azaltzeko.

Nolanahi ere, Kripkek hitzaldiak eman zituenerako Descartesen estiloko metafisika dualistak ez zeuden batere modan, eta filosofo gehien-gehienak 
materialistak ziren. Ez da zaila materialista izan nahi izateko motiboak aurkitzea: gure zientziek munduaren azalpena ematea nahi dugu, eta, zentzuren batean fisikoa edo materiala ez den zerbaiten presentzia onartzen badugu munduan, zaila da ikusten nola azal dezaketen zientziek horren izaera, edota, behin unibertsoko ia fenomeno guztiek izaera materiala daukatela onartuta, gutxienez deseroso egiten da salbuespen bakartzat animalion gogo-egoerak sartu behar izatea - ez da ulertzen zergatik izan beharko lukeen horrek salbuespen bakarra-. Materialismoaren alde egin nahi izateko motibo ugari aurkitu daiteke eta, modu bertsuan, N\&Nko hitzaldien garaian ideia materialista horri forma emateko proposamen ugari ere bazegoen. Bazeuden, adibidez, tradizio neopositibistari eutsiz "konduktista logikoak" zirenak, gogo-egoera oro kondukta mota bat edo kondukta mota baterako disposizioa dela ziotenak. ${ }^{20}$ Horiez gain,jarrera materialistarik sinpleena, ziur asko, gogo-egoerak eta gorputz-egoerak gauza bat eta berbera direla defendatzea litzateke; alegia, identitate-erlazio bat dagoela bi egoera mota horien artean. ${ }^{21}$ Halaber, 1970erako jada nahiko ezaguna zen aurreko hamarkadan Putnam eta beste batzuek garatu zuten jarrera funtzionalista, hein handi batean bai jarrera konduktisten eta bai identitate-teorien oinordekoa dena, baina horiek baino proposamen nahikoa sofistikatuagoa egiten duela esan dezakeguna. ${ }^{22,23}$

Kripke, berriz, anti-materialista da, dualista. Noski, ez da dualista Descartes dualista zen modu berean: Kripkek ez dio gogoa eta materia bi substantzia metafisiko desberdin direnik, berea "propietate-dualismo" bat da. Alegia, Kripkeren iritziz gauza bakarra dago hor, zu, zure gorputza edo zure garuna nahi baduzu, baina gauza horrek izaera metafisiko desberdina daukaten bi propietate dauzka: gogo-egoera bat (mina) eta egoera fisiko bat (garun-konfigurazio bat). Egoera horiek ez dira gauzak edo substantziak unibertsoan, baizik eta zuk edo zure garunak dauzkazuen propietateak. Garrantzitsua dena: propietate horiek metafisikoki oso desberdinak dira euren artean, minaren moduko gogo-egoerak ez baitira propietate fisikoak, baizik eta propietate mentalak (eta propietate mentalen izaera ez da propietate fisiko edo materialena bezalakoa). Horrelakoei buruz Kripkek ez du gehiegi esaten ez $N \& N n$ ez beste inon, ez du bere ikuskera dualista askorik garatzen. Bai ematen du, zehaztasun handiz, argudio anti-materialista bat hirugarren hitzaldian. Eta, argudioaren funtsa bera agian aspaldikoa izanik ere (badauzka lotura estuak Descartesen argudio dualista modalarekin), Kripkeren bertsioa oso berria da; izan ere, aurreko hitzaldietan aurkeztu dituen erreminta modalak erabiltzen

${ }^{20}$ Ikus, adibidez, Ryle (1949) —nahiz eta Rylek enpirista logikotik edo neopositibistatik oso gutxi izan-.

21 Ikus, adibidez, Smart (1959).

22 Ikus, adibidez, Putnam (1960), Lewis (1966) eta Fodor (1968).

${ }^{23}$ Funtzionalismoa, berez, neutrala da dualisten eta materialisten arteko eztabaidari dagokionez, baina egia da oso ondo ezkontzen dela ikuskera materialistarekin, eta autore funtzionalista gehienek jarrera materialista batekin konbinatu ohi dutela euren funtzionalismoa. 
ditu argudioaren bertsio berri hori emateko. Erreminta berri horiek auzi eta eztabaida filosofikoak planteatzeko modu berriak nola irekitzen dituzten, hori ikustea interesatzen zaigunez, esango ditut hemen gauza (gutxi) batzuk argudio anti-materialista horri buruz.

Kripkeren argudioa ondo ulertzeko, eta argudio horrek aurreko hitzaldietan aurkeztutako makineria modala nola erabiltzen duen ondo ulertzeko, garrantzitsua da kontuan izatea nola ikusten zuten Kripkek jomugan zeuzkan autore materialista horiek deskribatzen ari ziren gogo-gorputz erlazio horien izaera modala. Azalpena erraztearren, identitate-teoria materialistetara mugatuko naiz hemen, eta, identitate-teoria horien artean, tipo-tipo teorietara $^{24}$-Kripkek berak Smart (1959)rena bezalako identitate-teorien aurka egiten $\mathrm{du}$, baina esaten dituenek berdintsu balio dute posizio konduktisten eta funtzionalisten aurka, edota geroago proposatu ziren gainjartze ${ }^{25}$-erlazioen aurka- Teoria horien arabera, identitate-erlazioa dago gogo-egoeren eta dagokien egoera fisikoen artean. Adibidez, har ditzagun minak eta C-zuntzen estimulazioa: gizaki baten garuneko C-zuntzak estimulatzen diren bakoitzean norbanako horrek mina sentitzen du, eta mina sentitzen duen bakoitzean C-zuntzak estimulatu zaizkiolako da, demagun. ${ }^{26}$ Identiate-teorien arabera, beraz, mina sentitzea C-zuntzen estimulazioa da; gogo-egoera horretan egotea (mina sentitzea) garun-egoera fisiko horretan egotea (C-zuntzen estimulazioa) da: bi egoera horiek bat eta berbera dira — ez daude bi egoera hor, edota gauza batek izan ditzakeen bi propietate desberdin, bakarra baizik-. "Min" eta "C-zuntzen estimulazioa" adierazpenek, beraz, estentsio bera daukate teoria horren arabera, eta gauza berari erreferitzen diote.

Berriz: Kripkeren argudioa eta bere izaera berritzailea ondo ulertzeko, komeni zaigu kontuan izatea nola ulertzen zuten identitatearen teoriko horiek gogo-gorputz erlazio horren izaera modala (esan dut lehenago). Izan ere, Kripkek bere hitzaldiak eman zituen garaian, nahiko ohikoa zen onartzea identitate-erlazio hori kontingentea dela. Alegia, teoriko horien arabera, mina C-zuntzen estimulazioa da izatez, baina izan zitekeen beste modu batera. Gerta zitekeen, adibidez, gizakiek minik ez sentitzea C-zuntzak estimulatzean, hotza baizik; edo inoiz ezer ere ez sentitzea, akaso (zonbi filosofikoak existi zitezkeen); eta gerta zitekeen, baita ere, gizakiek mina sentitzea ez euren C-zuntzak estimulatu direlako, baizik eta beste zonalderen bat estimulatu delako (gizakiok izan genezakeen fisiologia desberdina). Gure mundua halakoa balitz, diote materialista hauek, mina ez litzateke izango C-zuntzen esti-

${ }^{24}$ Kripkek identitate-teoriaren bi bertsioren artean bereizten du: badago tipo-tipo identitateteoria eta badago ale-ale identitate-teoria. Kripkeren argudioak berdintsu balio du bi teoria moten aurka, eta tipo-tipo teoriei buruz dihardu batez ere Kripkek N\&Nn. Nik ere horrela egingo dut, bada.

25 Supervenience, ingelesez.

${ }_{26}$ Gaur egun badakigu teoria hori okerra dela, ez dela C-zuntzen estimulazioa minen oinarrian dagoena. 
mulazioa, identitate-erlazio hori ez litzateke gertatuko. Baina mundu erreal honetan bai, izatez, mina C-zuntzen estimulazioa da, eta identitate-erlazio bat dago bi egoera horien artean.

Nahiko erraza da ulertzen zergatik onartzen zuten hainbatek, Kripkeren hitzaldiak baino lehenago, identitate-erlazio horiek, izatekotan, kontingenteak izango direla. Aurrena, begi-bistakoa da "Mina C-zuntzen estimulazioa da" gisako perpausak a posteriori direla egiazkoak, egiazko izatekotan. Hori, mina eta C-zuntzen artean dagoen korrelazio hori, ez da norbaitek gogoeta hutsez eta a priori ezagut dezakeen zerbait: aurkikuntza zientifiko bat da, ebidentzia enpirikoaren oinarrian ezagutzera irits gaitezkeen zerbait. Beraz, bai, bi egoera horien artean korrelazioa dagoela erakutsi digu zientziak, baina, printzipioz behintzat, erakuts ziezagukeen bestela: ikerketa zientifikoak erakuts ziezagukeen mina sentitzen dugun bakoitzean hori ez dela C-zuntzak estimulatzen zaizkigulako, baizik eta bestelako egoeraren bat gertatzen delako geure nerbio-sisteman. Nolanahi ere, izatez, mina C-zuntzen estimulazioa dela erakutsi digu zientziak. Beraz, bai, badago identitate-erlazio bat garun-egoera eta gogo-egoera horien artean, nahiz eta bestela izan zitekeen eta, horregatik, erlazio hori kontingentea da.

Gogo-egoeren eta garun-egoeren artean horrelako identitate-erlazio kontingenteak daudela onartzen duenak, normalean, antzeko zerbait esango du zientziek egin ohi dituzten antzeko aurkikuntzei buruz ere. Horien arabera, zientziek erakutsi digute ura $\mathrm{H}_{2} \mathrm{O}$ dela, argia fotoi-sorta dela, edo beroa molekula-mugimendua dela, eta zientziek berdin-berdin erakutsi digute mina Czuntzen estimulazioa dela. Horiek guztiak, diote, zientziek aurkitu dituzten identitate teorikoak dira. Orain, erlazio horiek guztiak, berriz, kontingenteak dira. Izan ere, aurreko paragrafoan aipatu dudan moduan, ikerketa zientifikoaren bitartez aurkitu dugu erlazio horiek gertatzen direla, baina gerta zitekeen beste modu batera. Erraz imajina dezakegu ura ez zitekeela $\mathrm{H}_{2} \mathrm{O}, \mathrm{XYZ}$ baizik, edo argia ez zitekeela fotoi-sorta bat, edo mina ez zitekeela C-zuntzen estimulazioa. Zientziek, beraz, kontingenteak diren gisa horretako identitate teorikoak erakusten dizkigute, eta gogo-gorputz identitate-erlazioak bat gehiago dira horrelako identitate teorikoen artean. Eta hori oso ondo datorkio materialistari. Izan ere, literatura filosofikoan zaharrak dira ikuskera materialisten aurkako "argudio modalak". Descartesek berak argudiatu zuen gogoak eta gorputzak bi substantzia metafisiko desberdin izan beharko dutela, bata bestea gabe existi zitekeelako: Jainkoak bi substantzia motak korrelatuta sortzea erabaki zuen, baina erabaki zezakeen bestela -Jainkoak sortu zezakeen materia gogorik gabe, edota sortu zezakeen gogoa materiarik gabe-. Identitate teorikoak oro har kontingenteak direla onartuz, beraz, materialistak erantzun diezaieke horrelako argudio modalei baietz, gogo-gorputz erlazioak izan zitezkeela beste moduren batekoak, baina, izatez, gogoa eta gorputza gauza bat eta bakarra direla, izatez ura eta $\mathrm{H}_{2} \mathrm{O}$ gauza bat eta berbera diren modu berean. 
Bada justu horixe da ezin dena izan, Kripkeren iritziz. Eta puntu honetantxe ikus dezakegu nola Kripkek bere hitzaldietan aurkezten duen makineria modala lagungarria izan daitekeen plaza filosofiko berriak irekitzeko, edota eztabaida eta argudio zaharrak modu berritzailean birplanteatzeko. Labur, mota honetako materialistei zera erantzuten die Kripkek: identitate teorikoak beharrezkoak dira egiazkoak badira eta, ustezko gogo-gorputz identitateari dagokionez, erlazio hori ez da beharrezkoa — faltsua da, beraz, identitate hori gertatzen dela-.

Kontua da, Kripkek dioenez, "ur", " $\mathrm{H}_{2} \mathrm{O}$ ", "bero" edo "molekula-mugimendu" gisako termino orokorrak designatzaile zurrunak direla, zentzuren batean behintzat. ${ }^{27}$ Mundu posibleren batean ura dagoela esaten badugu, adibidez, mundu horretan ura dagoela esaten ari gara, alegia, geure mundu errealean "ur" deitzen dugun gauza horixe beraxe; izen propio batek mundu posible orotan objektu berbera designatzen duen moduan, "ur" bezalako klase natural termino batek substantzia berbera designatzen du mundu posible orotan. Noski, "ur" terminoa zurruna bada, berdin izango da zurrun " $\mathrm{H}_{2} \mathrm{O}$ " gisako termino bat. Beraz, "Ura $\mathrm{H}_{2} \mathrm{O}$ da" baiezpenak identitate-erlazio bat predikatzen du, bi designatzaile zurrun erabilita: ikusi dugu lehenago horrelako perpausak beharrezkoak direla egiazkoak badira. Egiazkoa denez, beraz, "Ura $\mathrm{H}_{2} \mathrm{O}$ da" identitate teorikoa beharrezkoa da (ez dago mundu posiblerik non ura ez den $\mathrm{H}_{2} \mathrm{O}$ ), eta berdin dira beharrezkoak "Argia fotoi-sorta da" eta "Beroa molekula-mugimendua da" perpausak.

Itzul gaitezen gogo-gorputz erlazioetara. Kripkek dioenez, erraz irudika dezakegu ustezko identitate-erlazio horiek ez direla gertatzen, eta hala onartzen zuen identitate kontingenteen teorikoak ere: erraz imajina dezakegu mundu posibleren batean Aneren C-zuntzak estimulatzen direla, baina Anek ez duela minik sentitzen, hotza baizik, edota Anek ez duela ezertxo ere sentitzen (zonbi bat da). Beraz, mundu horretan behintzat mina ez da C-zuntzen estimulazioa. Eta kontua da bai "C-zuntzen estimulazioa" eta bai "mina" designatzaile zurrunak direla biak. Garun-egoera bat designatzeko erabiltzen dugu "C-zuntzen estimulazioa", eta adierazpen hori mundu posible bat deskribatzeko erabiltzen dugunean, mota horretako egoera bat designatzen dugu mundu horretan. Berdin "min"ekin. Izan ere, bi egoeren kasuan propietate esentzial bat erabiltzen dugu egoera horiek identifikatzeko: zerbait ezin da C-zuntzen estimulazioa izan ez bada egoera fisiko hori, eta zerbait ezin da mina izan ez bada sentsazio hori. Beraz, bai "C-zuntzen estimulazioa", bai "mina" designatzaile zurrunak direnez, lehenago azaldu dudanez, "C-zuntzen estimulazioa mina $d a$ " perpausa beharrezkoa izango da, egia

\footnotetext{
27 Putnam (1975)ek tesi ia berberak defendatzen ditu. Biologian eta kimikan egiten diren identitate teorikoen beharrezkotasunari buruz, eta gisa honetako termino orokorrak designatzaile zurrunak direlako ideiari buruz, ikus ale honetan bertan aurki daitekeen Michael Devitten artikulua.
} 
bada. Baina ez da beharrezkoa. Beraz, faltsua da: mina eta C-zuntzen estimulazioa bi gauza desberdin dira, eta ez dago identitate-erlaziorik garun-egoera eta gogo-egoeren artean. Materialismoa faltsua da. Hori da Kripkeren argudio anti-materialista.

Materialista saia daiteke identitate teorikoekin egin duen analogiari eusten. Izan ere, modalitateen inguruko bere iritzien oinarrian ere, Kripkek ez luke ukatuko, adibidez, ura $\mathrm{H}_{2} \mathrm{O}$ denik, identitate-erlazio hori gertatzen denik —zientzialariek irakasten digute hori horrela dela-. Eta ez, Kripkek ez du halakorik ukatzen. Ale honetarako itzuli dugun bigarren hitzaldiaren amaieran aipatzen du, hirugarren hitzaldiaren hasieran nahikoa detailean garatzeko, "Ura $\mathrm{H}_{2} \mathrm{O}$ da" perpausaren gisakoak egiazkoak direla eta, beraz, beharrezkoak. Perpaus horrek kontingentea dirudi: sentsazioa daukagu faltsua gerta zitekeela -azken finean ura $\mathrm{H}_{2} \mathrm{O}$ dela aurkitu genuen, baina sentsazioa daukagu gerta zitekeela beste moduren batean, aurkitu ahal genuela ura ez dela $\mathrm{H}_{2} \mathrm{O}$, baizik eta XYZ, adibidez-. Kontingentea dirudi, baina ez da (dio Kripkek). Gertatzen dena da beharrezkoa dela, baina a posteriori. Badago mundu posible bat geure mundu errealarekiko kualitatiboki identikoa dena, baina zeinean "Ura $\mathrm{H}_{2} \mathrm{O}$ da" perpausak zerbait faltsua adierazten duen. Mundu horretan, demagun, nire doppelgänger bat bizi da, eta mundu hori nik bezalaxe bizi du: nik izan ditudan esperientzia igual-igualak izan ditu, kolore berberak ikusi ditu, soinu berberak entzun ditu, hizkuntza (ia) berbera ikasi du baldintza berberetan. Desberdintasun bakarra da mundu horretan nire doppelgängerrak eta bere mundukideek "ur" deitzen dutena ez dela $\mathrm{H}_{2} \mathrm{O}$, baizik eta, demagun, XYZ, eta, horregatik, nire doppelgängerrak eskolan ez duela ikasten ura $\mathrm{H}_{2} \mathrm{O}$ dela, baizik eta "Ura XYZ da" perpausaren bitartez adierazten duen zerbait. Hori ez da ura $\mathrm{H}_{2} \mathrm{O} e z$ den mundu bat (dio Kripkek), mundu horretan ez baitago urik, antzeko substantzia bat baizik. Nolanahi ere, kualitatiboki geure munduarekiko identikoa da (mundu horretan bizi den nire doppelgängerrak nik mundu hau bizi dudan bezalaxe bizi du bere mundua), eta mundu horretan "Ura $\mathrm{H}_{2} \mathrm{O}$ da" perpausak bai adierazten du faltsua den zerbait. Horregatik da a posteriori ura $\mathrm{H}_{2} \mathrm{O}$ dela, eta horregatik kontingentea dirudi, nahiz eta beharrezkoa den.

Beraz, badirudi materialistak esan dezakeela antzeko zerbait gogo-gorputz identitateei buruz: identitate horiek gainontzeko identitate teorikoak bezalakoak dira, beharrezkoak, nahiz eta kontingenteak diruditen (baina ez dira). Kripkek ondo irakatsi digun moduan, minaren eta C-zuntzen estimulazioaren arteko erlazioa beharrezkoa da, eta ez dago mundu posiblerik non mina ez den C-zuntzen estimulazioa. Beharrezkoa da, baina a posteriori, eta, horregatik, kontingentea dirudi: iruditzen zaigu badagoela mundu posible bat non norbaiten C-zuntzak estimulatzen diren, baina ez duen minik (hori zen Kripkeren argudio anti-materialistako lehenengo premisa). Nolanahi ere, kontingentzia itxura hori ez da itxura besterik, benetan ez dago horrelako mundurik. Eta azal dezakegu kontingentzia-itxura hori Kripkek urarekin eta 
$\mathrm{H}_{2}$ Orekin egin duen bezalaxe: mundu kualitatiboki identikoen bitartez azal dezakegu zergatik dirudien gogo-gorputz erlazio horrek kontingentea hala izan gabe.

Eta azkeneko horixe da Kripkek ukatzen duena (tira, aurreko guztia ere bai). "Mina C-zuntzen estimulazioa da" perpausaren kontingentzia-itxura ezin da "Ura $\mathrm{H}_{2} \mathrm{O}$ da" perpausaren kontingentzia-itxura azaldu dugun modu berean azaldu. Izan ere, mundu posible bat geure mundu honekiko identikoa bada kualitatiboki, mundu honetan daukagun min berbera izango dugu han. Demagun, adibidez, badagoela mundu bat non nire doppelgänger bat dagoen, mundu hori nik mundu erreal hau bizi dudan moduan bizi duena: mundu erreala nik eta mundu posible hori nire doppelgängerrak berdin-berdin bizi ditugu "barrutik". Hori horrela bada, nik izan ditudan min berberak izango ditu nire doppelgängerrak (bestela mundu hori eta hau ez lirateke kualitatiboki "identikoak" izango, ez lirateke berdin sentituko). Hau da, ezin da gertatu mundu posible bat geure munduarekiko identikoa izatea kualitatiboki, baina mundu horretan ez egotea minik, baizik eta mina "dirudien" baina mina ez den beste zerbait. Izan ere, zerbaitek mina dirudi baldin eta bakarrik baldin mina bada (sentsazioen kasuan itxurak izatea egiten du). Badago mundu posible bat non norbaiten C-zuntzak estimulatzen diren baina minaren ordez hotza sentitzen duen: hotza sentitzen duela iruditzen bazaio eta ez mina, hotza dauka, eta ez mina. Eta baldin badago mundu zonbi bat non Aneren C-zuntzak estimulatzen diren baina Aneri ez zaion iruditzen mina sentitzen duela, orduan mundu horretan Anek ez dauka minik, minari esentziala baitzaio sentsazioa (ez dago sentitzen ez den minik). Berriz: zentzugabea da esatea sentitzen duena benetan mina dela, nahiz eta ez dirudien, nahiz eta minaren ordez hotza dirudien, edo, besterik gabe, ez den sentitzen. Halako mundu posiblerik badagoela iruditzen bazaigu, badagoelako da, eta, horregatik, ez da beharrezkoa mina C-zuntzen estimulazioa izatea, eta faltsua da mina C-zuntzen estimulazioa dela. Materialismoa faltsua da (berriz).

Noski, materialista saia daiteke argudioari erantzuten. Edozein kasutan, $N \& N n$ garatutako aparatu modala erabilita Kripkek erakusten du materialistak ezin duela argudiatu ustezko gogo-gorputz identitate-erlazio horiek kontingenteak direla, edo, bestela, erlazio horiek beharrezkoak direla, baina euren kontingentzia-itxura bestelako identitate teorikoen kontingentzia-itxura azaltzen den modu berberean azaldu daitekeela. Ziur asko, argudioaren lehenengo premisa ukatzea da materialistak eskura daukan aukera onena, bakarra ez bada. ${ }^{28}$ Nolanahi ere, Kripkek N\&Nn aurkezten dituen erremintek erakusten dute gogo-gorputz materialismoak, tradizio luzeko posizio filosofiko horrek, uste zena

\footnotetext{
28 Materialistak, adibidez, zalantzan jar dezake egoera kontrafaktiko bat imajinatu ahal izateak erakusten duela egoera hori metafisikoki posible dela —ikus, adibidez, Balog (1999), Hill eta McLaughlin (1999), Perry (2001) eta Yablo (2002)—. Kripkeren defentsan, eta argudioaren bertsio berri baterako, ikus, batez ere, Chalmers $(1996,2009)$.
} 
baino ate gutxiago dauzkala irekita, eta erreminta horiexek balio izan dute eztabaida zahar horiek modu berri eta argiagoan birplanteatzeko.

\section{Ale honi buruz}

Gogoaren ale berezi honetan, bada, bi artikulu original eta itzulpen bat bildu ditugu. Michael Devittek (CUNY) "Gogoeta batzuk Naming and Necessityri buruz" artikulua idatzi du (eta Kepa Kortak euskarara ekarri), María de Pontek "Kripke, Perry eta 'ni'" artikulua, eta nik neuk N\&Nko bigarren hitzaldia itzuli dut.

Akaso normalagoa lirudike, N\&Nko hitzaldietako bat itzultzen hasita, lehenengoa hautatzea, baina bigarren hitzaldia euskaratzeari aproposago iritzi diogu. ${ }^{29}$ Izan ere, bigarren hitzaldi horretan ematen ditu Kripkek deskriptibismoaren aurkako bere argudio eta kontradibide ezagunenak, hor aurkezten du kate kausal-historikoen "irudi hobea", eta bertan defendatzen du, baita ere, izen propioez osatutako identitate-baiezpenak beharrezkoak direla beti (nahiz eta batzuetan horiek a posteriori bakarrik diren ezagugarriak); horregatik iritzi diogu hitzaldi horixe euskaraz izatea aproposa izan daitekeela Hizkuntzaren Filosofiako irakasgaietan Kripkeren ideiak azaldu eta ulertu nahian dabiltzan irakasle eta ikasle euskaldunentzat. Noski, hitzaldi horretan Kripkek proposatzen dituenak egoki ulertzeko komeni da, gutxienez, lehenengo hitzaldian defendatu dituen tesi batzuk eta erabili dituen nozio eta kontzeptu batzuk gogoan izatea. Nolanahi ere, Kripkek bigarren hitzaldian egiten dituen baiezpen ia guztiak nahiko erraz uler daitezke lehenengo hitzaldian defendatu dituen tesi gehienak kontuan izan gabe, eta, erabiltzen dituen kontzeptu eta nozioei dagokienez, saiatu naiz horiek sarrera (ez hain) labur honetan aurkeztu eta argitzen. Behin sarrera hau irakurrita, zuzenean N\&Nko bigarren hitzaldiari heltzea ez dela hain zaila izango espero dut, beraz.

Michael Devittek "Gogoeta batzuk Naming and Necessityri buruz" artikulua idatzi du, bere obran han-hemen $N \& N k o$ ideia batzuen inguruan egin dituen gogoetak artikulu bakarrean bilduz. Kripkek N\&Nn egiten dituen proposamen batzuei errepasoa egiten die, Devittek berak defendatu izan dituen ideia batzuekin lotuz, eta Kripkeren ideia batzuek jaso izan dituzten kritika batzuei erantzunez. Devittek aspalditik aztertu ditu Kripkek N\&Nn garatzen dituen ikuskerak —artikuluan dioenez, 1970ean Kripkek hitzaldiak eman baino lehenago ezagutzen zituen Devittek horiek jada, Harvarden Kripkek eman zuen graduko ikastaro batean izan zuelako horien berri-. Kripkeren anti-deskriptibismoak eta erreferentziaren gaineko bere "irudi berriak" eragin handia izan du Devit-

29 Bide batez, hau ez da Kripkeren testu bat euskarara ekartzen den lehenengo aldia: Agustin Arrietak "Identitatea eta Beharrezkotasuna" itzuli zuen orain dela urte batzuk; Arrieta (2001)en argitaratu zen, eta Korta (2007)n berrargitaratu. 
tek hamarkadetan zehar defendatu duen izen propioen "teoria kausalean". ${ }^{30}$ Ale honetan argitaratu dugun artikuluan, aurrena, N\&Nn aurki daitezkeen deskriptibismoaren aurkako argudio batzuei errepasoa egiten die Devittek, batez ere berak "Ezjakitea eta Akatsa" deitzen dion argudioan jarriz arreta. Ondoren, $N \& N r e k i n$ lotu ohi diren bi ideia aztertzen ditu, eskuordetze-erlazioak eta erreferentzia zuzena, kritikoki. Azken ataletan, Devittek Kripkeren esentzialismoaren alde egiten du, hiru esentzialismo motaren artean bereiziz: klase biologikoen eta kimikoen esentzialismoak, eta esentzialismo indibiduala. N\&Nn Kripkek defendatzen duen ideia da bai klase naturalek eta bai norbanakoek badauzkatela propietate esentzialak. Biologiaren filosofo ugarik kritikatu izan du Kripkeren esentzialismoa ez dela bateragarria ikuskera darwinistarekin. Devittek ukatu egiten du hori hala denik, eta azkeneko atal horietan Kripkeren esentzialismo aristotelikoaren defentsa laburra aurkezten du.

Azkenik, María de Pontek "Kripke, Perry eta 'ni'" artikulua idatzi du, berriki Kripkek indexikoei buruz esan dituenak kritikoki aztertuz. N\&Nn Kripkek ez ditu indexikoak ia aipatu ere egiten; erreferentziaz aritzean izen propioetara, deskripzio definituetara eta klase natural terminoetara mugatzen da batez ere. Nolanahi ere, izen propio eta klase naturalei buruz proposatzen dituenek irekitzen dituzte bide berriak, eta, ziur asko, proposamen horiek badaukate eragina 1970eko hamarkadan zehar filosofo ugarik indexikoei buruz esan zituztenetan. ${ }^{31}$ Baina 2011n Philosophical Troubles argitaratu zen, Kripkek idatzitako artikulu-bilduma; bildutako testuetatik batzuk lehenago argitaratuta zeuden jada, baina beste batzuen kasuan argitaratzen ziren lehenengo aldia zen, nahiz eta horietako gehienak urte dezente lehenago idatziak izan. Hori da "Frege's Theory of Sense and Reference" eta "The First Person" testuen kasua; lehenengoan Fregeren zentzu eta erreferentzien teoriari buruz ohar batzuk egiten ditu, eta bigarrenean "ni" lehen pertsonako kontzeptuari buruz hausnarketa batzuk plazaratzen ditu. Horiei heltzen die de Pontek bere artikuluan. Besteak beste, Kripkeren proposamenak John Perryren ekarpenekin konparatzen ditu, azken honen alde eginez. Izan ere, de Pontek dioenez, besteak beste, artikulu horietan Kripkek esaten dituenak aldendu egiten dira Kripkek berak $N \& N n$ ireki zuen bidetik, eta gai horietaz aritzean justifikatu gabeko aurresuposizioak egiten ditu, niaren ikuskera kartesiar batekin konprometitzen ei baita, hartarako arrazoi gehiegirik eman gabe.

\section{Erreferentziak}

ArrietA, Agustin (arg). 2001. Egia Motak. Donostia: UPV/EHU. Austin, John Langshaw. 1962. Sense and Sensibilia. Oxford: Oxford University Press. BALOG, Katalin. 1999. "Conceivability, possibility, and the mind-body problem". Philosophical Review 108: 497-528.

30 Ikus, adibidez, Devitt (1974, 1981, 2001).

31 Ikus, adibidez, Perry (1977, 1979), Lewis (1979) eta Kaplan (1989). 
BarCan Marcus, Ruth. 1946. "A Functional Calculus of First Order Based on Strict Implication". Journal of Symbolic Logic XI: 1-16.

BARCAN MARCUS, Ruth. 1947. "The Identity of Individuals in a Strict Functional Calculus of Second Order". The Journal of Symbolic Logic 12 (1): 12-15.

BarCAN Marcus, Ruth. 1961. "Modalities and Intensional Languages". Synthese 13: 303-22.

BARCAN MarCus, Ruth. 1990. “A Backward Look at Quine's Animadversion on Modalities". In R. Barrett eta R. Gibson (arg.), Perspectives on Quine. Oxford: Blackwell, 230-243.

CARnAP, Rudolf. 1947. Meaning and Necessity. Chicago: University of Chicago Press.

Chalmers, David. 1996. The Conscious Mind. New York: Oxford University Press.

Chalmers, David. 2009. "The Two-Dimensional Argument Against Materialism". In B. McLaughlin (arg.), Oxford Handbook of Philosophy of Mind. Oxford: Oxford University Press, 313-35.

Davidson, Donald eta Gilbert Harman (arg.). 1972. Semantics of Natural Language. Boston, Massachusetts: Reidel Publishing Company.

DeviTt, Michael. 1974. "Singular Terms". Journal of Philosophy 71: 183-205.

DeviTT, Michael. 1981. Designation. New York: Columbia University Press.

DeviTT, Michael. 2001. "A Shocking Idea About Meaning". Revue Internationale de Philosophie 208: 449-72.

Donnellan, Keith. 1966. "Reference and Definite Descriptions". The Philosophical Review 75 (3): 281-304. [Euskarazko itzulpena: 2007. "Erreferentzia eta Deskripzio Definituak". In Korta (arg.), 173-94. Itzultzailea: Kepa Korta]

Donnellan, Keith. 1977. "The contingent a priori and rigid designators". Midwest Studies in Philosophy 2 (1): 12-27.

Evans, Gareth. 1979. "Reference and Contingency". The Monist 62 (2): 161-89.

FoDOR, Jerry. 1968. Psychological Explanations. New York: Random House.

Hill, Christopher eta Brian McLaughlin. 1999. "There are fewer things in reality than are dreamt of in Chalmer's philosophy." Philosophy and Phenomenological Research 59: 445-54.

HintikKA, Jaakko. 1963. "The Modes of Modality". Acta Philosophica Fennica 16: 65-82.

JeSHION, Robin (arg.). 2010. New Essays on Singular Thought. Oxford: Oxford University Press.

KANGER, Stig. 1957. Provability in Logic. Stockholm: Almquist and Wiksell.

Kaplan, David. 1989. "Demonstratives". In J. Almog, J. Perry eta H. Wettstein (arg.), Themes from Kaplan. New York: Oxford University Press, 481-565.

KorTA, Kepa (arg.). 2007. Hitzaren Lilura. Hizkuntzaren Filosofiako Irakurgaiak. Donostia: EHU Argitalpenak.

KRIPKE, Saul Aaron. 1959a. "A Completeness Theorem in Modal Logic". The Journal of Symbolic Logic 24 (1): 1-14.

KRIPKE, Saul Aaron. 1959b. "Semantical Analysis of Modal Logic". The Journal of Symbolic Logic 24 (4): 323-24.

KrIPKE, Saul Aaron. 1963. "Semantical Considerations on Modal Logic". Acta Philosophica Fennica 16: 83-94.

KRIPKE, Saul Aaron. 1971. "Identity and Necessity". In M.K. Munitz (arg), Identity and Individuation. New York: New York University Press, 135-64. Berrargitaratua in Kripke 2011, 1-26. [Euskarazko itzulpena: 2001. "Identitatea eta Beharrezkotasuna". In Arrieta (arg), 140-74. Berrargitaratua in Korta (arg.) 2007, 195-229. Itzultzailea: Agustin Arrieta.] 
KRIPKE, Saul Aaron. 1980. Naming and Necessity. Cambridge, Massachusetts: Harvard University Press.

KrIPKE, Saul Aaron. 2011. Philosophical Troubles: Collected Papaers. New York: Oxford University Press.

Kunn, Thomas. 1962. The Structure of Scientific Revolutions. Chicago: University of Chicago Press.

LEwIS, Clarence Irving. 1918. A Survey of Symbolic Logic. Berkeley: University of California Press.

LewIS, Clarence Irving eta Cooper Harold LangFord. 1932. Symbolic Logic. New York: Century Company.

LEwIS, David. 1966. "An Argument for the Identity Theory". Journal of Philosophy 63: 17-25.

LEwIS, David. 1968. "Counterpart Theory and Quantified Modal Logic". Journal of Philosophy 65: 113-26.

LewIS, David. 1979. "Attitudes de dicto and de se". Philosophical Review 88: 513-43.

MorrIS, Errol. 2011. "The Ashtray: The Ultimatum (Part 1)". Opinionator, The New York Times, 2011, martxoak 6. https://opinionator.blogs.nytimes.com/2011/03/06/the-ashtray-the-ultimatum-part-1/

Pérez Otero, Manuel. 2006. Esbozo de la filosofía de Kripke. Bartzelona: Montesinos.

PERrY, John. 1977. "Frege on Demonstratives". The Philosophical Review 86 (4): 474-97. [Euskarazko itzulpena: 2007. "Frege erakusleez". In Korta (arg.), 243-75. Berrargitaratua in Gogoa 17: 89-118. Itzultzailea: Kepa Korta].

Perry, John. 1979. "The Problem of the Essential Indexical". Nous 13 (1): 3-21.

Perry, John. 2001. Knowledge, Possibility and Consciousness. Cambridge: MIT Press.

Putnam, Hilary. 1960. "Minds and Machines". In S. Hook (arg.), Dimensions of Mind. New York: New York University Press, 138-64.

Putnam, Hilary. 1975. "The Meaning of 'Meaning'”. In H. Putnam, Mind, Language and Reality. Philosophical papers vol. 2. Cambridge, Massachussetts: Cambridge University Press, 215-71.

Quine, Willard van Orman. 1947. "The Problem of Interpreting Modal Logic". Journal of Symbolic Logic XII: 43-48.

Quine, Willard van Orman. 1951. "Two Dogmas of Empiricism". Philosophical Review 60: 20-43. [Euskarazko itzulpena: 2001. "Enpirismoaren bi dogma". In Arrieta (arg.), 112-39. Itzultzailea: Agustin Arrieta]

Quine, Willard van Orman. 1953a. "Reference and Modality". In Quine, From a logical point of view. New York: Harvard University Press, 139-59.

Quine, Willard van Orman. 1953b. "Three Grades of Modal Involvement". Proceedings of the XIth International Congress of Philosophy 14: 65-81.

Russell, Bertrand eta Alfred North Whitehead. 1910-3. Principia Mathematica. Cambridge: Cambridge University Press.

RyLE, Gilbert. 1949. The Concept of Mind. London: Hutcheson.

SMART, John Jamieson Carswell. 1959. "Sensations and Brain Processes". Philosophical Review 68: 141-56.

SMITH, Quentin. 1995. "Marcus, Kripke, and the Origin of the New Theory of Reference". Synthese 104 (2): 179-89.

YABLO, Stephen. 2002. "Coulda, woulda, shoulda". In T. S. Gendler eta J. Hawthorne (arg.), Conceivability and Possibility. Oxford: Oxford University Press, 441-92. 